\title{
Expression of Nerve Growth Factor Receptors by Schwann Cells of Axotomized Peripheral Nerves: Ultrastructural Location, Suppression by Axonal Contact, and Binding Properties
}

\author{
Megumi Taniuchi, ${ }^{1}$ H. Brent Clark, ${ }^{2}$ John B. Schweitzer, ${ }^{3}$ and Eugene M. Johnson, Jr. ${ }^{1}$ \\ 'Department of Pharmacology, Washington University School of Medicine, St. Louis, Missouri 63110, 2Department of \\ Laboratory Medicine, Memorial Medical Center, Springfield, Illinois 62781, and ${ }^{3}$ Division of Neuropathology, Department of \\ Pathology, College of Medicine, University of Tennessee, Memphis, Tennessee 38163
}

\begin{abstract}
Axotomy of sciatic nerve fibers in adult rats induces expression of NGF receptor in the entire population of Schwann cells located distal to the injury (Taniuchi et al., 1986b). In the present study we have used immunocytochemistry, with a monoclonal antibody directed against the rat NGF receptor, to examine axotomized peripheral nerves by light and electron microscopy. We have found that (1) the NGF receptor molecules were localized to the cell surface of Schwann cells forming bands of Bungner; (2) axonal regeneration into the distal portion of sciatic nerve coincided temporally and spatially with a decrease in Schwann cell expression of NGF receptor; (3) Schwann cell NGF receptor could be induced by axotomy of NGF-independent neurons, such as motoneurons and parasympathetic neurons; and (4) the presence of axon-Schwann cell contact was inversely related to expression of Schwann cell NGF receptor. Using biochemical assays we have found that, in striking contrast to peripheral nerves, there was no detectable induction of NGF receptor in the spinal cord and brain after axotomy of NGF receptorbearing fibers. Filtration assays of ${ }^{125}$ I-NGF binding to the induced NGF receptors of Schwann cells measured a $K_{d}$ of $1.5 \mathrm{nM}$ and a fast dissociation rate, both characteristics of class II receptor sites. We conclude that Wallerian degeneration induces Schwann cells, but not central neuroglia, to produce and position upon their plasmalemmal surface the class II NGF receptor molecules. The induction is ubiquitous among Schwann cells, irrespective of the type of axon they originally ensheathed. Expression of Schwann cell NGF receptor is negatively regulated by axonal contact, being induced when axons degenerate and suppressed when regenerating axons grow out along the Schwann cell surface. We propose that the induced NGF receptors function to bind NGF molecules upon the Schwann cell surface and thereby
\end{abstract}

\footnotetext{
Received Apr. 16, 1987; revised July 29, 1987; accepted Aug. 13, 1987.

We thank Dr. Charles Chandler for generously providing the hybridoma cells secreting monoclonal antibodies 192-IgG and 151. We thank Patricia A. K. Osborne, James J. Minesky, and Carl Grgurich for excellent assistance. This work was supported by a grant from the Monsanto Company, by Multiple Sclerosis Society Grant RG-1540A1, and by National Institutes of Hcalth National Rcsearch Award (Molecular, Biochemical, and Physiological Pharmacology) GM07805 from the National Institute of General Medical Sciences.

Correspondence should be addressed to Megumi Taniuchi, Ph.D., Department of Pharmacology, Box 8103, Washington University School of Medicine, 660 South Euclid Avenue, St. Louis, MO 63110.

Copyright (C) 1988 Socicty for Neuroscience $0270-6474 / 88 / 020664-18 \$ 02.00 / 0$
}

provide a substratum laden with trophic support and chemotactic guidance for regenerating sensory and sympathetic neurons.

NGF is an essential trophic agent which promotes survival and cellular metabolism of sympathetic neurons and neural crestderived sensory neurons of the PNS (for review, see Thoenen and Barde, 1980). In addition, NGF may exert similar effects on some populations of cholinergic neurons in the CNS (see Hefti and Weiner, 1986). Numerous studies have shown that depriving developing peripheral neurons of NGF by any one of several experimental protocols, including passive transfer of antiNGF antibodies, induction of autoimmune anti-NGF antibodies, and mechanical or chemical ablation of axonal termini, causes the selective killing of sensory and sympathetic neurons (as reviewed by Purves and Lichtman, 1985). The cell death resulting from experimental isolation of these NGF-dependent neurons from their target tissue can be prevented by the administration of exogenous NGF (Johnson et al., 1986). Furthermore, recent work has shown that NGF is also produced in the CNS (Shelton and Reichardt, 1984; Korsching et al., 1985), that central neurons bear NGF receptors (Taniuchi et al., 1986a), and that NGF appears to exert trophic actions on cholinergic neurons of the basal forebrain (medial septal nucleus, nucleus basalis, and nucleus of the diagonal band of Broca) (Honegger and Lenoir, 1982; Gnahn et al., 1983; Hefti, 1986).

The sequence of events by which NGF exerts its trophic activity on responsive neurons appears to involve synthesis of NGF by tissues innervated by these neurons, receptor-mediated uptake of NGF at the axonal termini, and retrograde axonal transport of NGF to the somata. Both NGF protein and mRNAencoding NGF have been detected in target organs of sympathetic innervation, such as the heart and iris muscles (Korsching and Thoenen, 1983a; Shelton and Reichardt, 1984). Retrograde axonal transport of exogenously administered radiolabeled NGF (Hendry et al., 1974) and of endogenous NGF molecules (Korsching and Thoenen, 1983b; Palmatier et al., 1984) has been demonstrated in sympathetic and sensory neurons of the PNS. Furthermore, blocking retrograde transport by physical axotomy or by pharmacological agents causes neuronal cell death similar to that observed with NGF deprivation (Thoenen and Barde, 1980; Purves and Lichtman, 1985).

Although the molecular mechanisms of NGF action have not been elucidated, it is known that the first step involves binding of NGF to specific cell surface receptor molecules. Studies of 
equilibrium NGF binding have shown that both sympathetic and sensory neurons contain 2 populations of binding sites, class I sites, with a $K_{\mathrm{d}}$ of $20 \mathrm{pm}$, and class II sites, with a $K_{\mathrm{d}}$ of $2 \mathrm{~nm}$ (Sutter et al., 1979a; Landreth and Shooter, 1980). The dichotomy of apparent affinities is a manifestation of different dissociation rates, the class I sites showing virtually no dissociation of NGF at low temperatures, the class II sites showing a very rapid dissociation rate ( $t_{1 / 2}$ of approximately $30 \mathrm{sec}$ ). Although the physiological significance of the 2 classes of receptor is unclear, several studies have suggested that internalization of NGF and the initiation of NGF biological activity are associated with NGF binding to the class I sites (Sutter et al., 1979b; Bernd and Greene, 1984; Vale et al., 1985).

Previous studies of NGF receptors in the adult animal have shown expression of the receptors to be restricted to NGFresponsive neurons of the PNS and CNS. We recently reported an exception to this generalization, namely, the induction in vivo of NGF receptor molecules in Schwann cells, the peripheral neuroglia that ensheathe PNS axons (Taniuchi et al., 1986b). Surgical transection of the sciatic nerve in adult rats causes a dramatic, time-dependent increase in the density of NGF-binding activity in nerve segments and organs located distal to the site of lesion. Over the course of a week, the density of receptors increases between 20- and 50-fold. In the absence of axonal regeneration, the receptor density in distal nerve remains at peak level for at least a week and then starts to decline, although at 5 weeks the density is still elevated above control values. Immunohistochemical staining with a monoclonal anitbody directed to the rat NGF receptor and examination at the lightmicroscopic level show the receptors to be localized to the entire population of Schwann cells of the endoneurium. All Schwann cells distal to axotomy show uniform immunostaining.

Several lines of investigation, both in vivo and in tissue culture, have shown that Schwann cells can promote axonal regeneration of both PNS and CNS neurons after nerve injury (see Aguayo et al., 1983). There are also reports that Schwann cells can produce NGF or NGF-like proteins after nerve injury (Rush, 1984; Finn et al., 1986; Korsching et al., 1986). On the basis of these results, of the fact that Schwann cells themselves are apparently unresponsive to NGF, and of our observation of NGF receptor induction in transected nerve, we proposed (Taniuchi et al., 1986b) that the expression of NGF receptors is part of the physiological response to nerve injury wherein Schwann cells produce trophic and tropic agents to promote axonal regeneration. Our hypothesis states that disruption of the normal interaction between Schwann cells and axons induces the Schwann cells to produce both NGF and the NGF receptor. The NGF binds to the cell surface receptors and becomes concentrated upon the substratum over which regenerating axons grow. Surface-bound NGF molecules supply trophic support and haptotactic guidance (chemotactic activity over a surface) for sympathetic and sensory axons regenerating through the bands of Bungner, with the Schwann cell processes arranged in longitudinal cords within the endoneurium. We have speculated that the production of NGF and its receptor is only part of a general activation of the Schwann cells that promotes axonal growth, and that the ability of peripheral sheath cells to respond in such a manner may contribute to the capacity of peripheral endoneurium to support axonal regeneration.

We have extended our study of the induction of NGF receptor in vivo in the context of its possible role in promoting axonal regeneration. Among numerous questions raised by our initial findings are the following: Where are the NGF receptor molecules located at the ultrastructural level; in particular, are they distributed in a manner whereby they could present bound NGF to regenerating axons? What is the effect of axonal regeneration on the expression of NGF receptors by Schwann cells? Is the ability to induce NGF receptor expression restricted to the subpopulation of Schwann cells ensheathing NGF-responsive neurons, or is it a general phenomenon? Are central neuroglial cells capable of similar induction after axonal injury? What are the binding properties of the NGF receptors induced in the sheath cells? We have addressed these points in the present study, and the results provide a further characterization of NGF receptor induction in vivo and provide support for the hypothesis that the induction is involved in promoting axonal regeneration.

\section{Materials and Methods}

Materials. The 2.5S subunit of NGF, purified from adult male mouse submaxillary glands according to the method of Bocchini and Angeletti (1969), was used in all experiments. The NGF was radioiodinated ( ${ }^{125} \mathrm{I}$; supplied by Amersham, Arlington Heights, IL) by a modification of the method of Marchalonis (1969), as described previously (Yip and Johnson, 1984). The radiolabeled NGF ( ${ }^{125} \mathrm{I}-\mathrm{NGF}$ ) was separated from nonincorporated ${ }^{125} \mathrm{I}$ and ${ }^{125} \mathrm{I}$-lactoperoxidase by gel filtration on a column $(1.5 \times 74 \mathrm{~cm})$ of Sephadex G-100 (Pharmacia Fine Chemicals). The specific radioactivities of the ${ }^{125}$ I-NGF preparations were within the range of 1900-2500 cpm/fmol. Monoclonal antibody 192-IgG (Chandler et al., 1984), directed against the rat NGF receptor molecule (Taniuchi and Johnson, 1985; Taniuchi et al., 1986a), was produced in ascites and purifed by affinity chromatography with protein A-Affi-Gel (BioRad), as previously described (Taniuchi et al., 1986a). Radioiodinated 192-IgG was prepared using the same protocol as for NGF and separated from nonincorporated ${ }^{25}$ I by gel filtration on Sephadex G-25M (PD10 columns; Pharmacia). The specific radioactivity of ${ }^{125}$ I-192-IgG ranged from 1800 to $2100 \mathrm{cpm} / \mathrm{fmol}$. Monoclonal antibody 151 , directed to EGF receptors (Chandler et al., 1985), was purified from tissue culture supernatants by affinity chromatography with protein A-Sepharose 4B (Pharmacia) and was used as control antibody. Polyclonal antibodies directed against $192-$ IgG were developed by immunization of New Zealand White rabbits (Boswell Breeders, Pacific, MO) and were affinitypurified on 192-IgG-Sepharose 4B. For use in immunohistochemistry, affinity-purified biotinylated horse anti-mouse IgG (heavy- and lightchain-specific) immunoglobulin, preadsorbed to remove crossreactivity to rat IgG, was purchased from Vector Laboratories (Burlingame, CA), as were the reagents for the avidin-biotin-horseradish peroxidase complex. The crosslinking agent 1-ethyl-3-(3-dimethylaminopropyl)carbodiimide hydrochloride (EDC) was purchased from Pierce. Formalin-fixed Staphylococcus aureus cells (Pansorbin) were obtained from Calbiochem, and electrophoresis reagents from Bio-Rad. All other reagents, unless specified, were purchased from Sigma. For brain lesion studies, female Sprague-Dawley rats (200-250 gm) from Harlan Breeders (Indianapolis, IN) were used. In all other experiments, male SpragueDawley rats (200-250 gm) supplied by Chappel Breeders (St. Louis, MO) were used.

Surgical procedures and collection of tissue samples. All animals were acquired, cared for, and surgically handled in accordance with the guidelines of the NIH Guide for the Care and Use of Laboratory Animals.

Bilateral axotomy of the sciatic nerve of chloral hydrate-anesthetized $(350 \mathrm{mg} / \mathrm{kg}$ ) rats was performed by either of 2 procedures. To axotomize and prevent regeneration, the sciatic nerve was exposed in the midgluteal region and ligated twice with 6-0 silk sutures (placed $2 \mathrm{~mm}$ apart) at the site where the nerve passes superficial to the tendon of the obturator internus muscle. The nerve was then transected between the ligations, its proximal stump was inserted beneath the tendon, and the distal stump reflected caudally. To achieve axotomy but allow subsequent regeneration of fibers into the distal portion, the nerve was crushed for $40 \mathrm{sec}$ with fine-tipped jewelers' forceps at the same site where the transections were performed in the previously described animals. The crush site was marked with a single epineural 8-0 monofilament nylon suture. After various time periods, the rats were anesthetized with ether and decapitated. For biochemical assay and immunohistochemical detection of the NGF receptor, the $2 \mathrm{~cm}$ length of nerve immediately distal to axotomy and the tibialis anterior muscle were removed. 
Unilateral ventral rhizotomy of the $\mathrm{L}_{s}$ root was performed as follows: The spinous processes of $L_{5}$ vertebra were exposed and the dorsal lamina removed under an operating microscope. An incision was made in the dura, and the cauda equina was exposed. The arachnoid was opened over the lateral spinal canal and the $\mathrm{L}_{5}$ fiber was transected, with the proximal stump reflected rostrally. Two weeks after the initial surgery, the rats were anesthetized and decapitated, and a $3 \mathrm{~cm}$ segment of sciatic nerve was removed at the midgluteal level.

Unilateral vagotomy was performed by exposing the carotid sheath by midline neck incision and blunt dissection between the sternohyoid and thyrohyoid muscles. The vagus nerve was isolated from the carotid artery and the preganglionic sympathetic nerve. Two ligations with 6-0 sutures were placed $1 \mathrm{~mm}$ apart at the level of the thyroid cartilage, and the nerve was transected between the ligations. The cut ends of the nerve were reflected away from each other. After 2 weeks, the rats were killed with an overdose of chloral hydrate and $1.2 \mathrm{~cm}$ segments of the vagus nerve distal and proximal to transection, as well as a $2 \mathrm{~cm}$ segment of the contralateral vagus nerve at the same level, were dissected.

Spinal cord double hemisection was performed as follows. The spinous processes of the thoracolumbar region were exposed. The paraspinal muscles were stripped, and the laminae of the thirteenth thoracic and first lumbar vertebrae were removed under an operating microscope. The underlying ligamentum flavum and the dura were incised to expose the spinal canal. The spinal cord was twice hemisected with a \#11 scalpel blade, once at the level of origin of the fourth and again at the level of the fifth lumbar roots. After 2 weeks the rats were anesthetized and decapitated, and the segment of spinal cord between the 2 hemisection lesions and $1 \mathrm{~cm}$ segments rostral and caudal to this segment were dissected.

For septohippocampal lesions, rats were anesthetized with ketamine $(87 \mathrm{mg} / \mathrm{kg})$ and xylazine $(13 \mathrm{mg} / \mathrm{kg})$ and were placed in a stereotactic apparatus (Kopf) with the incisor bar $3.3 \mathrm{~mm}$ below the interaural line. After creating bilateral burr holes lateral to the longitudinal suture, fine scissors were introduced $1.3 \mathrm{~mm}$ caudal to bregma and $3 \mathrm{~mm}$ lateral to the longitudinal suture at a $30^{\circ}$ angle. The scissors were inserted to a depth of $5 \mathrm{~mm}$, with the tips held $4 \mathrm{~mm}$ apart, and were then closed and opened 3 times. Following the appropriate survival time, the animals were anesthetized with ether and decapitated. The brains were removed, placed on a glass petri dish positioncd on icc, and dissectcd under a microscope. The cerebral cortex overlying the hippocampus was removed by blunt dissection; the structures ventral to the hippocampus were removed by using a combination of blunt and sharp dissection. The ventral half of the hippocampus was then removed. An area that included the medial septal nucleus and the vertical limb of the nucleus of the diagonal band of Broca was obtained by cutting a coronal section of brain from $1.2 \mathrm{~mm}$ rostral to bregma, at the level where the corpus callosum appears, to $0.3 \mathrm{~mm}$ caudal to bregma, at the level where the anterior commissure disappears. A triangular wedge approximately $6 \mathrm{~mm}$ on a side, was then cut out of the base of the brain. Control tissues were obtained by identical dissection of unmanipulated rats, which were matched for age, size, and sex with the experimental animals.

The optic nerve was transected unilaterally by first extending the lateral fissure of the orbit by incisions of the skin and orbicularis oculi muscle, reflecting the lateral rectus muscle, and then severing the exposed optic nerve with fine scissors. The skin incision and the tarsus were sutured to prevent corneal dehydration and trauma to the eyeball. After 2 weeks the rats were anesthetized and decapitated, and both the lesioned and contralateral optic nerves (both anterior to the optic chiasma) were dissected.

Tissue preparation for immunohistochemistry. The tissue samples were handled differently depending on how they were to be examined. For light-microscopic examination, the sciatic nerves and tibialis anterior muscles were removed when the animal was killed, and fixed for 12 $24 \mathrm{hr}$ by immersion in paraformaldehyde ranging in concentration from 0.5 to $4.0 \%$. After fixation, the tissues were immersed in Tissue-Tek O.C.T. (Miles Scientific, Naperville, IL) and frozen in liquid $\mathrm{N}_{2}$. Nerves used for electron-microscopic examination were fixed by immersion in $4 \%$ paraformaldehyde for $12-24 \mathrm{hr}$ and then dehydrated in increasing concentrations of polyethylene glycol (PEG; average $M_{r}, 1000 \mathrm{Da}$ ) according to the method of Smithson et al. (1983). After dehydration, the nerves were infiltrated in $100 \%$ PEG and embedded in the type of tissue cassettes routinely used for paraffin-embedded tissue blocks. These PEGembedded blocks were stored at $4^{\circ} \mathrm{C}$ until they were sectioned.

Light-microscopic immunohistochemistry. Frozen sections $10 \mu \mathrm{m}$ thick were made with a cryostatic microtome and mounted on chrome-alumcoated glass slides. The tissue sections were processed for immunostaining with either $192-\mathrm{IgG}$ or control antibody, as previously described (Taniuchi et al., 1986b). Axonal neurofibrils were silver-stained by the method of Sevier and Munger (1965).

Electron-microscopic immunocytochemistry. Tissue sections $(25 \mu \mathrm{m})$ of nerves were made from PEG-embedded blocks on a rotary microtome at $20^{\circ} \mathrm{C}$. These sections were incubated in tissue culture wells for 30 min in PBS containing 3\% normal goat serum (NGS), 3\% lysine, and $0.02 \% \mathrm{NaN}_{3}$. The sections were exposed to $192-\mathrm{IgG}$ or control monoclonal antibody $(5 \mu \mathrm{g} / \mathrm{ml})$ in PBS containing $5 \%$ horse scrum and $0.02 \%$ $\mathrm{NaN}_{3}$. After treatment with primary antibody overnight at $4^{\circ} \mathrm{C}$, the sections were washed in PBS, pH 7.5. Biotinylated horse anti-mouse IgG immunoglobulin $(1 \mu \mathrm{g} / \mathrm{ml})$ was applied to the sections for $3 \mathrm{hr}$ at $22^{\circ} \mathrm{C}$. The sections were then washed in PBS and incubated for $2.5 \mathrm{hr}$ at $22^{\circ} \mathrm{C}$ with a complex of avidin and biotinylated horseradish peroxidase. After several washes, the sections were incubated for 10-12 min in 3,3'-diaminobenzidine $/ 0.01 \% \mathrm{H}_{2} \mathrm{O}_{2}$. The sections were washed in $100 \mathrm{~mm}$ PBS, and postfixed for $12-24 \mathrm{hr}$ in $2 \%$ glutaraldehyde at $4^{\circ} \mathrm{C}$. The sections were washed again and further fixed in $1 \%$ osmium tetroxide and $1.5 \%$ potassium ferricyanide for $2 \mathrm{hr}$ at $4^{\circ} \mathrm{C}$. After the osmium fixation, the tissue sections were washed, dehydrated through graded concentrations of ethanol, and infiltrated and flat-embedded in Spurr's plastic (Spurr, 1969). Ultrathin sections were cut on an LKB ultramicrotome and examined with a Philips 200 or a Hitachi 600 electron microscope without further counterstaining.

Assay for NGF receptor. Two assays were used to measure the NGF receptor in tissue homogenates cleared of intact cells and nuclei $\left(S_{2}\right.$ fraction, prepared according to the method of Costrini and Bradshaw, 1979; protein measured by the method of Lowry et al., 1951). The first method, as previously described (Taniuchi et al., 1986a, b), involved crosslinking ${ }^{125}$ I-NGF $(2 \mathrm{nM})$ to the receptor with EDC, solubilizing with $2 \% n$-octyl glucopyranoside, and then immunoprecipitating the radioligand-labeled receptor with monoclonal antibody 192-IgG. The immunoprecipitates were further chromatographed by SDS-PAGE (Laemmli, 1970) and quantitated by excising the portions of the gels containing the 90 and the $220 \mathrm{kDa}$ crosslinked species and measuring the radioactivity in a gamma counter. This protocol, which affords high sensitivity (capable of detecting $0.1 \mathrm{fmol}$ of crosslinked receptor in 5 $\mathrm{mg}$ of tissue), was used for samples of tibialis anterior muscle, spinal cord, and brain. The second method, modified from a previously described protocol (Taniuchi and Johnson, 1985), was a filtration assay to measure binding of ${ }^{125} \mathrm{I}-192-\mathrm{IgG}$ to the receptor. The $\mathrm{S}_{2}$ fraction was incubated in binding buffer (PBS/0.2\% BSA $/ 0.05 \% \mathrm{NaN}_{3}$ ) with ${ }^{125} \mathrm{I}$ $192-\operatorname{IgG}\left(5 \mathrm{nM}\right.$, the $K_{\mathrm{d}}$ of the antibody) for $1.5 \mathrm{hr}$ at $22^{\circ} \mathrm{C}$. Nonsaturable binding was determined by parallel incubations in the presence of nonlabeled $192-\mathrm{IgG}$ at $500 \mathrm{~mm}$. The free ${ }^{125} \mathrm{I}-192-\mathrm{IgG}$ was then removed by filtration through Millipore HVLP membrane disks (which had been hydrated with ice-cold binding buffer immediately before sample application) and rapid washing with three $3-\mathrm{ml}$ aliquots of ice-cold binding buffer (total wash time, approximately $11 \mathrm{sec}$ ). The disks were then measured for radioactivity. The filtration assay is faster than the crosslinking/immunoprecipitation assay and allows processing of more samples. However, it suffers from a higher level of nonsaturable radioligand association and therefore was unsuitable for assaying samples with very small amounts of NGF receptor, such as the brain, spinal cord, and muscle. Both assays showed linear increases of specific binding with increased amounts of $S_{2}$ protein, in the range of $0-1 \mathrm{mg}$ for the crosslinking/immunoprecipitation assay and $0-500 \mu \mathrm{g}$ for the filtration assay (data not shown). All samples were therefore assayed within these ranges.

Measurement of equilibrium binding and dissociation. The filtration assay described above was adapted to determine equilibrium binding of ${ }^{125}$ I-NGF and ${ }^{125}$ I-192-IgG to $S_{2}$ fractions and to measure the rates of dissociation of these ligands. For equilibrium-binding studies, $40 \mu \mathrm{g}$ of $\mathrm{S}_{2}$ protein was combined with radiolabeled ligand in binding buffer at $22^{\circ} \mathrm{C}$ for $1.5 \mathrm{hr}$. The radioligand concentration was varied from 50 pM to $50 \mathrm{nM}$, and nonsaturable binding was determined by parallel incubations with nonlabeled ligand present at $1 \mu \mathrm{M}$. At the end of the incubation, the samples were passed through Millipore HVLP membrane disks, as described above, and the radioactivity associated with the disks was measured.

The dissociation of these ligands was determined by a protocol similar to that described by Landreth and Shooter (1980), with necessary adaptations for processing tissue homogenates. Forty micrograms of $S_{2}$ protein were combined with $50 \mathrm{pm}$ of ${ }^{125} \mathrm{I}-\mathrm{NGF}$ or with $5 \mathrm{nM}$ of ${ }^{125} \mathrm{I}-$ 
192-IgG and incubated at $22^{\circ} \mathrm{C}$ for $1.5 \mathrm{hr}$. To determine nonsaturable binding, parallel samples were incubated with $500 \mathrm{nM}$ of nonlabeled ligand. The low concentration of ${ }^{125}$ I-NGF should favor binding to the high-affinity, slowly dissociating, class I binding sites (Landreth and Shooter, 1980). After equilibrium had been reached, the tubes were placed in an ice bath $\left(0.4^{\circ} \mathrm{C}\right)$ for $10 \mathrm{~min}$, which was sufficient to achieve homogeneous cooling. Nonlabeled ligand, also at $0.4^{\circ} \mathrm{C}$, was then added to 500 nм final concentration to initiate dissociation, and, at various times, samples were passed through the Millipore disks and the disks washed and subsequently measured for radioactivity, as described above.

Mechanical stimulation test. The length of the most rapidly regenerating sensory fibers after sciatic nerve crush was measured by mechanically stimulating the nerve (Young and Medawer, 1940; Rich and Johnson, 1985). At 6 and $7 \mathrm{~d}$ postaxotomy, the rats were anesthetized with ether and the sciatic nerve reexposed. Under light anesthesia, the rats were tested for reflex activity in response to gentle squeezing of the sciatic nerve with jewelers' forceps. The compressions were advanced stepwise ( $1 \mathrm{~mm}$ progressions) in a distal-to-proximal direction until a reaction was elicited, and the distance between the site of stimulation and the original site of nerve crush (marked with an epineurial suture) was measured.

CAT assay. Homogenates of hippocampus and of medial septal nucleus/vertical limb of diagonal band of Broca were assayed for CAT activity by the method of Schrier and Shuster (1967).

\section{Results}

\section{Ultrastructural localization of induced NGF receptors}

We previously determined that the induced NGF receptor molecules are localized to Schwann cells by using monoclonal $192-$ IgG as a specific immunohistochemical marker for receptor proteins (Taniuchi et al., 1986b). To examine the location of these receptors at the ultrastructural level, and, in particular, to ascertain whether they are situated on the Schwann cell plasmalemma, we have extended our analysis by use of electron-microscopic immunocytochemistry. The sciatic nerve of adult male Sprague-Dawley rats was surgically transected. Seven days later, when the Schwann cells of the distal sciatic nerve contained maximal levels of NGF receptor (Taniuchi et al., 1986b; see also Fig. 2), the nerves were dissected and processed for 192IgG immunohistochemistry and electron microscopy, as described in Materials and Methods. Within the segment of sciatic nerve located 2-20 mm distal to the site of transection, the 192IgG immunoreactivity was restricted to cells and cell processes identifiable as Schwann cells by their ultrastructural morphology and by their investment by basal lamina, as shown in Figure $1 A$. The larger immunostained cells often contained or bordered upon myelin debris and degenerating axons, but they shared the same basal lamina with numerous smaller processes that frequently had dense 192-IgG surface immunoreactivity (Fig. 1B). There were also groups of heavily immunoreactive cell processes of smaller caliber, which were similarly bounded by a basal lamina but lacked myelin debris or axons, as shown in Figure $1 C$. The positively immunostained structures associated with degenerating myelinated fibers are early bands of Bungner, and the densely stained, smaller-caliber structures are the unmyelinated equivalents of bands. In both types of bands, the 192-IgG immunoreactivity was most pronounced on the surfaces of the cell processes, indicating that the NGF receptors are located on the Schwann cell plasmalemma. Occasionally there was staining of the cytoplasm as well (Fig. $1 D$ ), presumably representing recently synthesized receptor molecules. No nuclear staining was detected.

There was no apparent predilection for 192-IgG immunostaining to be associated with Schwann cell surfaces that were in close apposition to the basal lamina, as opposed to those situated away from the basal lamina. The only cells that were immunoreactive with 192-IgG were those enclosed within a basal lamina (i.e., Schwann cells), and there was no immunostaining of cells that could be identified as macrophages or endoneurial fibroblasts. Electron-microscopic examination detected no immunoreactivity of Schwann cells when the sections were stained with control monoclonal antibody (not shown). Furthermore, in sections of control sciatic nerves containing no degenerating fibers (from rats not receiving surgical manipulations), there was no detectable immunostaining with 192-IgG (not shown). This is consistent with the biochemical data showing extremely low levels of NGF receptor in intact nerves (Taniuchi et al., 1986b; see also Fig. 2).

\section{Effect of axonal regeneration on expression of $N G F$ receptors by Schwann cells}

Our initial studies of NGF receptor induction were made with nerves in which axonal regeneration was prevented by completely transecting the nerve, reflecting the proximal stump dorsally, and inserting the distal stump into the deep gluteal muscles. In these animals, the axons distal to the transection degenerate, leaving nerve remnants consisting primarily of Schwann cells forming bands of Bungner within the endoneurium. Under these conditions, in segments of nerve distal to the lesion and within structures previously innervated by the nerve, such as the tibialis anterior muscle, the density of receptor increased dramatically over the course of a week and remained at peak level for at least another week (Taniuchi et al., 1986b). By 5 weeks posttransection the density in distal nerve segments had declined to a value approximately 10 -fold above control level, but the density in muscle showed no decrease. Immunohistochemical examination of tibialis anterior muscle showed that the receptors were confined to Schwann cells within nerve remnants and were not present on myocytes or connective tissue.

In the current study we examined the influence of regenerating axons on Schwann cell expression of NGF receptors. The sciatic nerve of adult rats was axotomized either by transection, to prevent regeneration, as in the previous study, or by applying a $40 \mathrm{sec}$ crush with jewelers' forceps to preserve the epineurial sheath and permit subsequent regeneration of axons. After periods up to 10 weeks, a distal segment of nerve and the tibialis anterior muscle were dissected from the animals, homogenized, and assayed for their content of NGF receptor molecules. The graph in Figure 2 shows the time course of the changes in NGF receptor density in the $2 \mathrm{~cm}$ segment of nerve immediately distal to the lesion site, and the graph in Figure 3 shows the time course obtained with the tibialis anterior muscle. In each tissue, the density of NGF receptor increased prominently during the first week, both when the nerves were crushed and when they were transected. This initial increase indicates that axotomy by nerve crush serves to induce NGF receptor expression distal to the site of lesion, although perhaps not as effectively as does transection.

If axonal regeneration into the distal region of nerve affects the expression of NGF receptor by the Schwann cells in that region, one would expect differences in receptor density between groups of animals with crushed nerves and those with transected nerves. Such differences were observed by both biochemical assay and immunohistochemical examination. Figure 3 (graph) shows that in the samples of tibialis anterior muscle, the density 

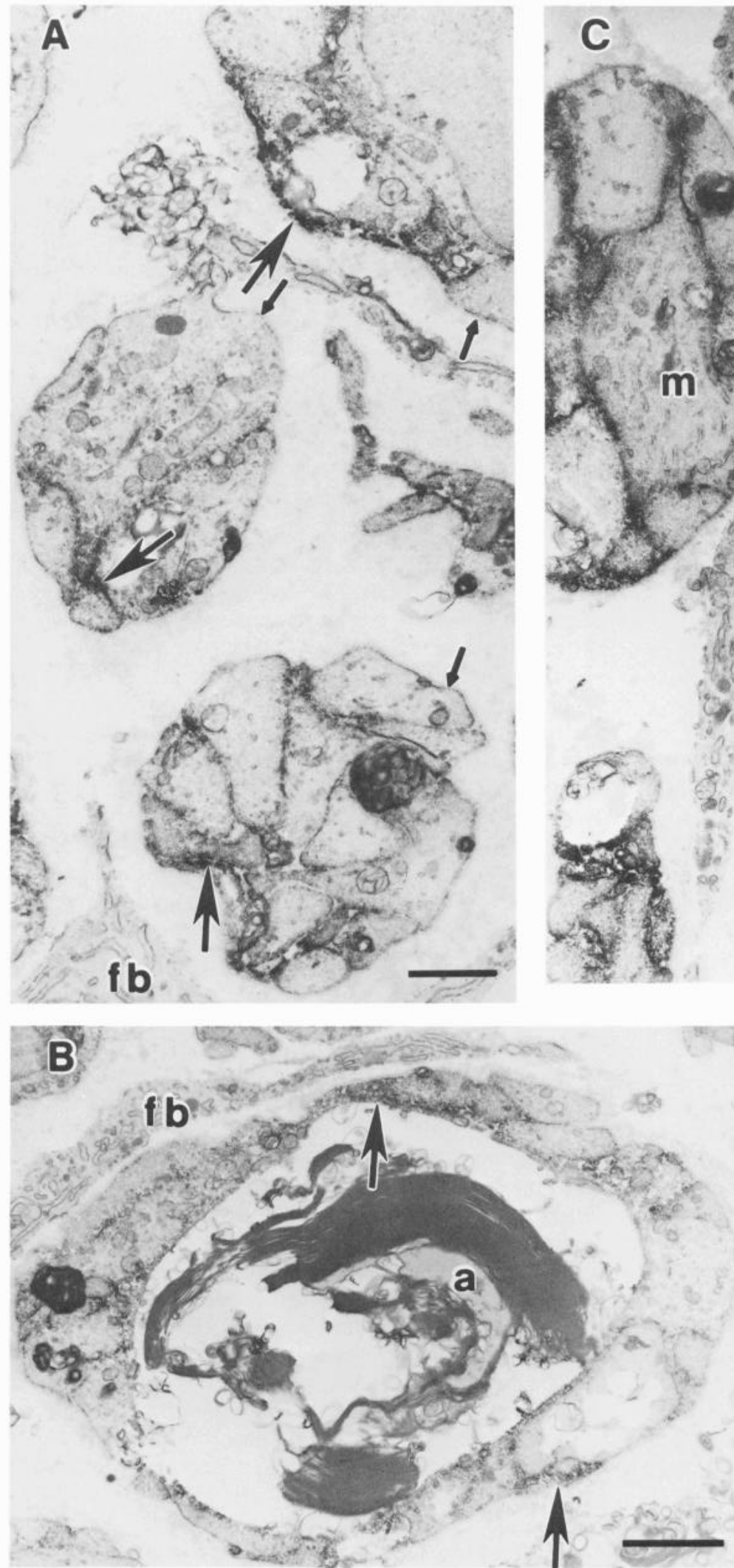
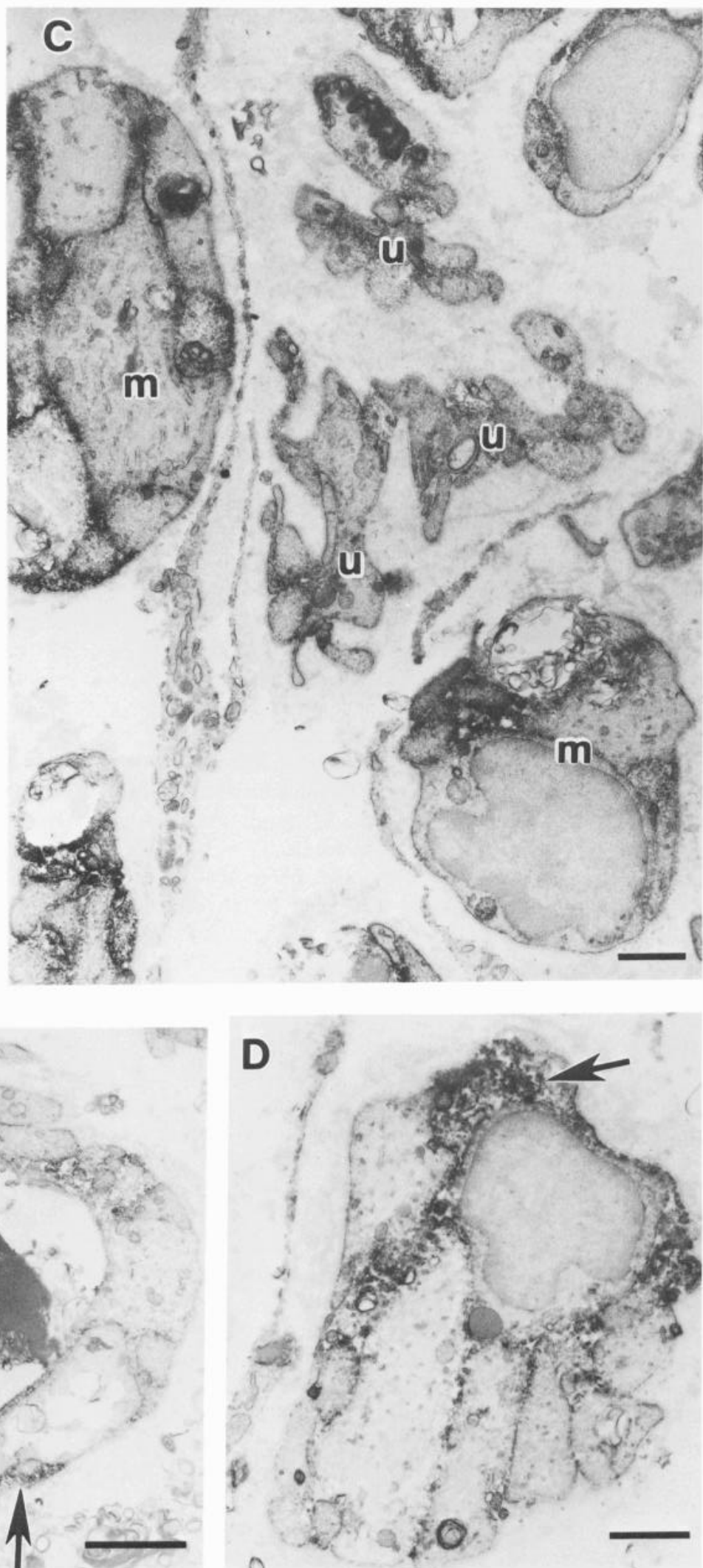

Figure 1. Electron-microscopic immunocytochemical localization of NGF receptors in the distal segment of sciatic nerve $7 \mathrm{~d}$ posttransection. $A$, Schwann cells and Schwann cell processes have dense surface immunostaining with 192-IgG (large arrows). All stained elements are contained within the original basal laminae (small arrows) of the Schwann cells. Scale bar, $1 \mu \mathrm{m}$. B, A band of Bungner containing a degenerating myelinated axon $(a)$ has numerous Schwann cell processes with 192-IgG immunostaining (arrows). An adjacent fibroblast $(f b)$ is unstained. Scale bar, $2 \mu$ m. $C$, Large and small bands of Bungner corresponding to Schwann cells originally associated with myelinated $(m)$ and unmyelinated $(u)$ fibers, respectively, both have 192-IgG immunoreactivity. Scale bar, $1 \mu \mathrm{m}$. D, Some Schwann cell processes (arrow) have 192-IgG immunoreactivity within the cytoplasm (arrow) as well as on the cell surfaces. Scale bar, $1 \mu \mathrm{m}$. 

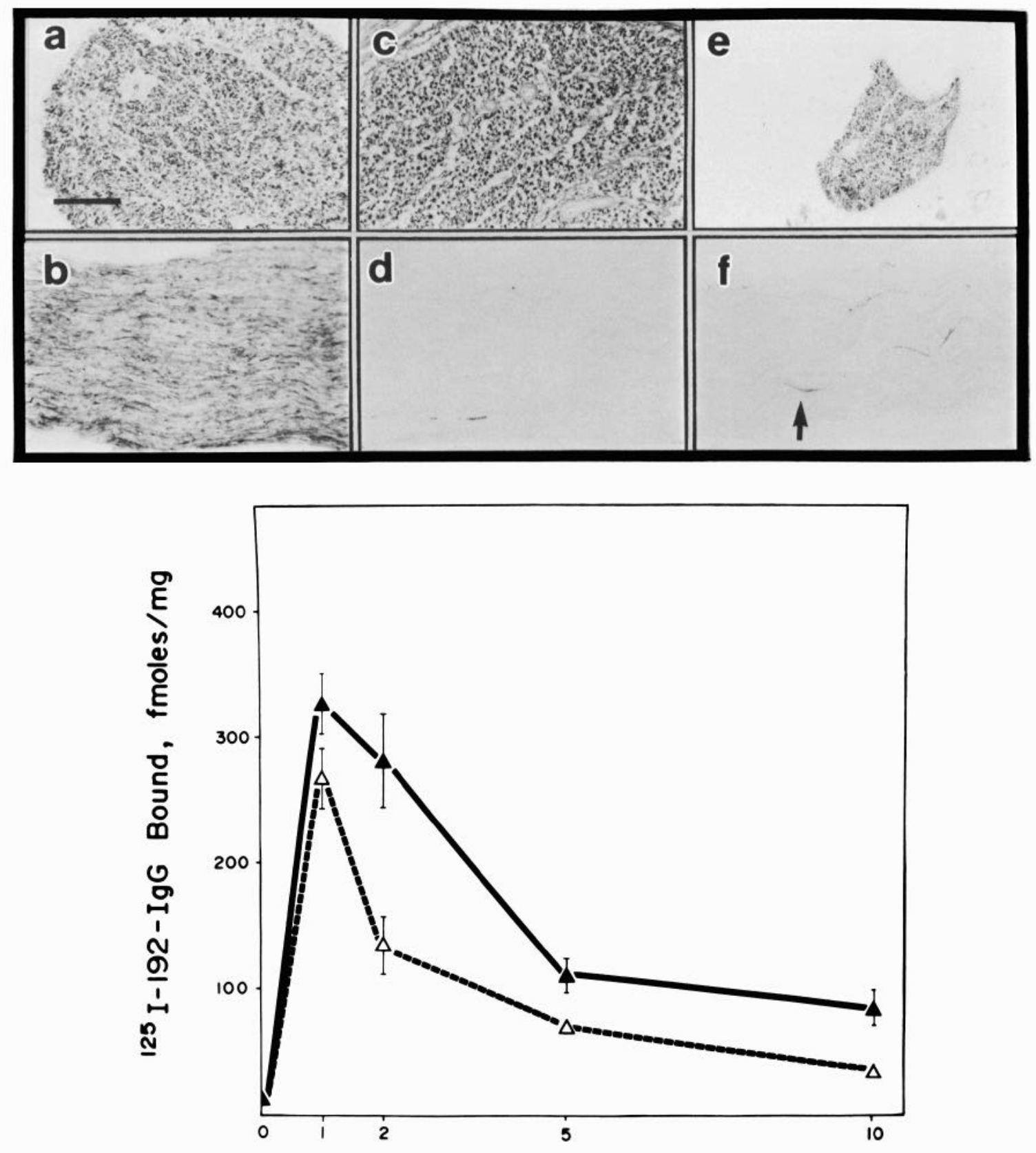

\section{Time Post-Axotomy, weeks}

Figure 2. NGF receptor in distal sciatic nerve after transection or crush injury. The sciatic nerve was axotomized either by transection, to prevent regeneration (closed triangles), or by epineurial crush to permit subsequent axonal regeneration (open triangles). Groups of rats ( $n=6$ for each type of axotomy at each time point) were killed at $1,2,5$, and 10 weeks after axotomy and the $2 \mathrm{~cm}$ section of nerve immediately distal to transection or crush was removed. The nerve segment from each rat was homogenized and centrifuged individually to obtain the $S_{2}$ fraction. The protein content of each $\mathrm{S}_{2}$ sample was determined, and then $100 \mu \mathrm{g}$ of protein from each sample was assayed in duplicate for NGF receptor by the ${ }^{125} \mathrm{I}-$ $192-\mathrm{IgG}$ binding/filtration assay. The values plotted are the mean \pm SD of the data from individual rats $(n=6)$. Error bars not shown fell within the dimensions of the symbols. Immunocytochemical localization. $a$, Transverse section 1 week posttransection, with all Schwann cells staining. $b$, Longitudinal section distal to the regeneration front 1 week after crush injury. Virtually all Schwann cells appear to be stained. $c$, Transverse section 5 weeks posttransection with all Schwann cells immunostained. $d$, Longitudinal section 5 weeks after crush injury. Axonal regeneration is nearly complete in this area and immunostaining is absent. There is a single blood vessel containing erythrocytes with peroxidase activity. $e$, Transverse section 10 weeks posttransection. The nerve fascicle and many of the Schwann cells are atrophic, but immunostaining is present on the Schwann cells. $f$, Longitudinal section 10 weeks after crush injury. Immunostaining is absent except for one apparent Schwann cell (arrow). Two blood vessels contain peroxidase-positive erythrocytes. Scale bar, $50 \mu \mathrm{m}$ for all sections.

of NGF receptor in animals with transected sciatic nerves increased approximately 10 -fold over the course of 2 weeks and then remained elevated for the 10 week duration of the experiment. In contrast, in animals receiving nerve crush, the receptor density fell after the 2 week period of initial rise. The reduction in receptor corresponded with reinnervation of the muscle, as ascertained by recovery of motor function in the lower limbs of the rats by 5 weeks postcrush. Immunohistochemical analysis 

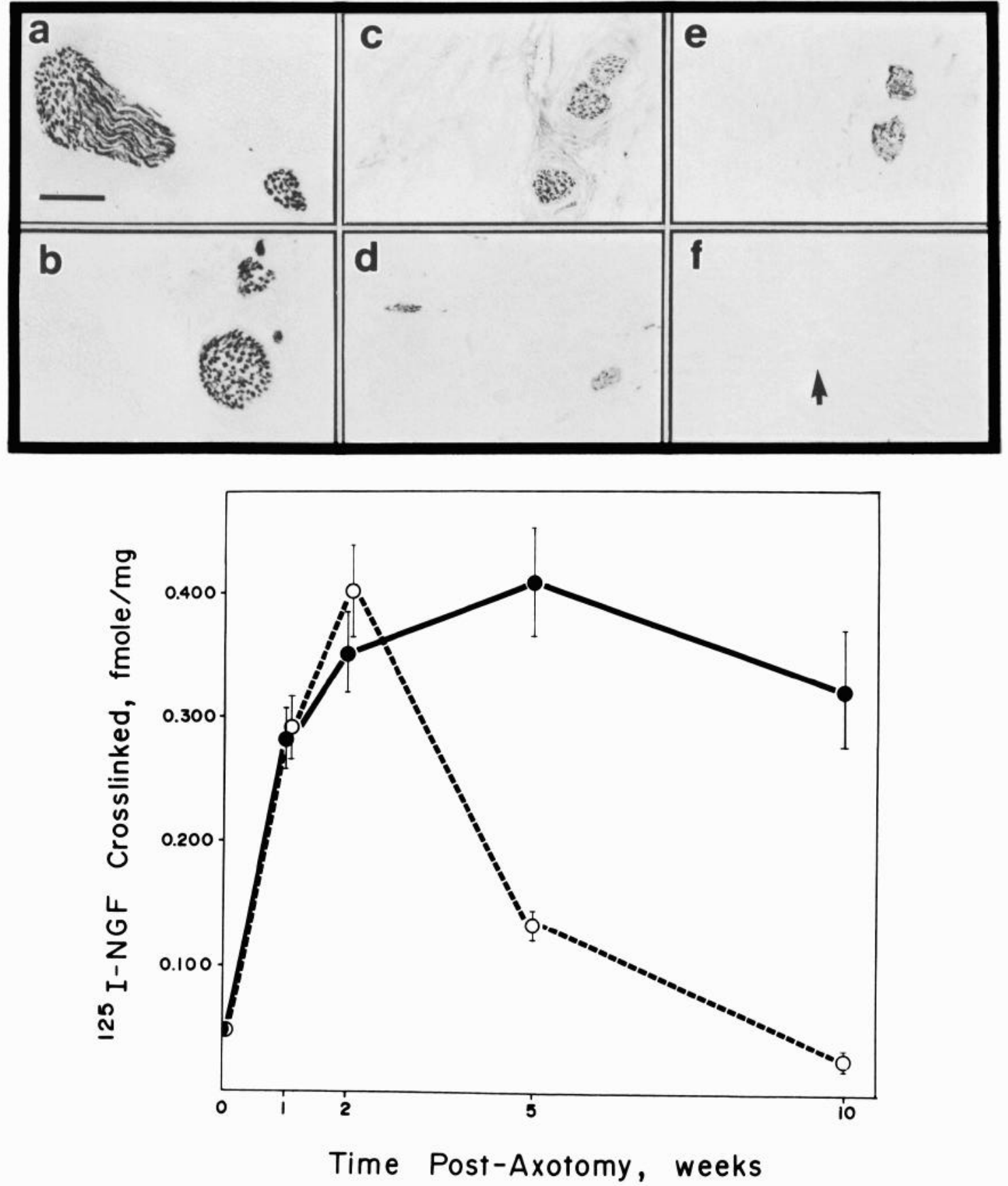

Figure 3. NGF receptor density in tibialis anterior muscle after sciatic nerve transection or crush. The tibialis anterior muscle was removed from each rat from the same experiment, as described in Figure 2. The muscles from each group of 6 rats were pooled, then homogenized and centrifuged to obtain the $S_{2}$ fraction. The protein content of the $S_{2}$ samples was determined, and then $500 \mu \mathrm{g}$ of each sample was assayed in triplicate with the ${ }^{125}$ I-NGF crosslinking/192-IgG immunoprecipitation assay. The values plotted represent the mean \pm SEM of the triplicate data obtained from muscle homogenates of rats that initially received nerve transection (closed circles) or nerve crush (open circles). Immunohistochemical localization. $a$, At 2 weeks posttransection, immunostaining is confined to Schwann cells in nerve fascicles within the muscle. $b$, Two weeks after crush injury the immunostaining pattern is identical to that obtained with sciatic nerve transection $(a)$. $c$, At 5 weeks posttransection, the immunostaining resembles that seen at 2 weeks. $d$, At 5 weeks after crush injury there is patchy immunostaining of Schwann cells in some small fascicles within the muscle. $e$. At 10 weeks posttransection there is immunostaining of the atrophic Schwann cells within nerve fascicles. $f$, At 10 weeks after crush injury the nerve fascicles (arrow) within the muscle have virtually no immunostaining of Schwann cells. Scale bar, $50 \mu \mathrm{m}$ for all sections.

with 192-IgG of tibialis anterior muscle $70 \mathrm{~d}$ after transection revealed staining of atrophied nerve fascicles (Fig. $3 e$ ), indicating that in the absence of reinnervation the Schwann cells continued to express NGF receptor.

In the $2 \mathrm{~cm}$ segment of distal nerve, NGF receptor density initially increased during the first week postaxotomy in both transected and crushed sciatic nerves (graph in Fig. 2). During the next week, the receptor density in crushed nerves decreased to one-half the value of that at 1 week postaxotomy, while the density in transected nerves remained at near-maximal levels. 
Beyond 2 weeks postaxotomy, the content of receptors continued to decline in the crushed nerves, and the receptor density also decreased in the transected nerves. Examination of the nerves by 192-IgG immunohistochemistry revealed the basis for these results (Fig. 2, $a-f$ ). In transected nerves, there was intense immunostaining of Schwann cells throughout the 10 week period, but the volume and number of Schwann cells within the endoneurium appeared to decrease (Fig. 2, $a, c, e$ ). Therefore, the decline in receptor content in the distal transected nerve segment reflects predominantly the loss and atrophy of the Schwann cells, and not of NGF receptor expression. In contrast, the crushed nerves showed heavy staining of Schwann cells only during the first 2 weeks (Fig. $2 b$ ). After that period, the staining of the sheath cells diminished progressively, although the number of Schwann cells in the nerve remained high (Fig. $2 d, f$ ). Results of the mechanical stimulation test, which measures the length of the most rapidly elongating sensory neuronal fibers, showed that the front of axonal regeneration was $1.57 \pm 0.06 \mathrm{~cm}(\mathrm{SEM} ; n=9)$ at $6 \mathrm{~d}$ postcrush, and $1.81 \pm 0.07$ $\mathrm{cm}$ (SEM; $n=10$ ) at $7 \mathrm{~d}$. Thus, by 1 week after nerve crush, much of the $2 \mathrm{~cm}$ distal segment measured for NGF receptor density contained regenerating axons. Therefore, in crushed nerves the decline in receptor density reflects a decrease in Schwann cell expression of NGF receptor, and this decline coincides temporally with the entry of regenerating axons.

To determine more precisely the spatial relationship of regenerating axons and the down-regulation of Schwann cell NGF receptor, we examined by 192 -IgG immunohistochemistry the region of crushed sciatic nerve containing the axon-regeneration front. Figure $4 A$ shows a segment of nerve immediately distal to a site of crush, stained for axons $6 \mathbf{d}$ after the lesion. Groups of regenerating axons, migrating distally (from left to right in Fig. 4), are darkly stained with silver at the left side of the photomicrograph. At higher magnification (Fig. $4 B$ ), smaller numbers of fibers can be discerned distal to the heavily stained region. Immunostaining of an adjacent section of the same nerve segment with 192-IgG shows greatly diminished immunoreactivity in the region containing the axons and a progressive increase in immunoreactivity when one examines areas distal to the regeneration front (Fig. 4, C, D). This demonstrates a clear spatial relationship between axonal regeneration and loss of Schwann cell NGF receptor. Ultrastructural examination of immunostained, transverse sections through the regeneration zone revealed a decrease or loss of NGF receptors in Schwann cells making contact with elongating axonal processes. As shown in Figure $4 E$, the Schwann cells and Schwann cell processes abutting neuronal surfaces have greatly diminished immunostaining compared to those not associated with axons. Thus, these results suggest that NGF receptor expression by Schwann cells is negatively regulated by interaction with axons. The loss of the normal Schwann cell-axon relationship causes an induction in NGF receptor production by the Schwann cells, and reestablishment of this interaction by axonal regeneration suppresses receptor expression.

\section{Induction of NGF receptor in Schwann cells ensheathing $N G F$-independent axons}

As we reported previously, and as is apparent in Figure 2, the entire population of Schwann cells within the sciatic nerve endoneurium distal to the site of axotomy is induced to express NGF receptor. This suggests that even those Schwann cells that originally ensheathed axuns of NGF-independent motoneurons are capable of expressing NGF receptor molecules after axotomy. There are several possible explanations for this ubiquitous induction. One is that any Schwann cell ensheathing a degenerating axon, irrespective of whether that neuron is NGF-responsive, becomes induced to express NGF receptor molecules. A second possibility is that degenerating NGF-responsive axons generate a local signal by releasing a diffusible agent that acts upon all nearby Schwann cells to induce NGF receptor expression.

To differentiate between these 2 possibilities, we selectively lesioned the motoneuron axons of the sciatic nerve by performing ventral rhizotomy. If only NGF-responsive neurons can generate the inducing agent, then there should be no induction of any Schwann cells following axotomy of NGF-independent motoneurons. If all Schwann cells are capable of inducing receptor following degeneration of the axons they ensheathe, then ablation of motor axons should cause receptor induction. If a diffusible signal is generated, then those Schwann cells ensheathing the degenerating axons and at least some Schwann cells in the vicinity of degenerating axons, but not actually ensheathing dying axons themselves, should all be induced. Figure $5 A$ shows a transverse section of a sciatic nerve 2 weeks after rhizotomy of the $L_{s}$ ventral root. Only those Schwann cells immediately surrounding degenerating motoneuronal axons stain with 192-IgG, indicating selective induction of NGF receptor in Schwann cells that have lost their direct interaction with neurons. In contrast, a completely transected sciatic nerve shows intense immunostaining of the entire population of Schwann cells (Fig. $5 B$ ).

The restricted induction of NGF receptor in those Schwann cells ensheathing degenerating axons was confirmed at the ultrastructural level. In rare instances, sciatic nerves from control rats contained spontaneously degenerating fibers. As shown in Figure $5 C$, the bands of Bungner associated with the degenerating axons stain with $192-\mathrm{IgG}$, but the other Schwann cells in the vicinity that ensheathe intact axons show no immunostaining. These results strongly suggest that the signal to induce NGF receptors is the loss of contact with viable axons, not the elaboration of a soluble factor.

The sciatic nerve is a mixed nerve, containing NGF-responsive sensory and sympathetic neurons and NGF-unresponsive motoneurons. To further establish that Schwann cells ensheathing NGF-unresponsive axons are capable of NGF receptor expression, we tested for induction of NGF receptor in the vagus nerve, which only contains axons of NGF-unresponsive neurons, namely, preganglionic parasympathetic fibers and fibers of placodally derived sensory neurons with somata located in the nodose ganglion. The vagus nerve was surgically transected in adult male rats at the level of the thyroid cartilage. A longitudinal section of the vagus nerve distal to site of axotomy, dissected and stained with 192-IgG 2 weeks after surgery, is shown in Figure 6. As was observed with transected sciatic nerve, the entire population of Schwann cells is induced to express NGF receptor. Quantitation of the induction by biochemical assay ( ${ }^{125} \mathrm{I}-192-\mathrm{IgG}$ binding) showed a 10.3 -fold increase in the density of NGF receptor by 2 weeks after transection, from 67.3 to $694.2 \mathrm{fmol} / \mathrm{mg}$.

\section{Testing for NGF receptor induction in the CNS}

The discrepancy between the ability of peripheral nerves to support axonal regeneration and the inability of central tracts to support regeneration has been described in numerous studies. 

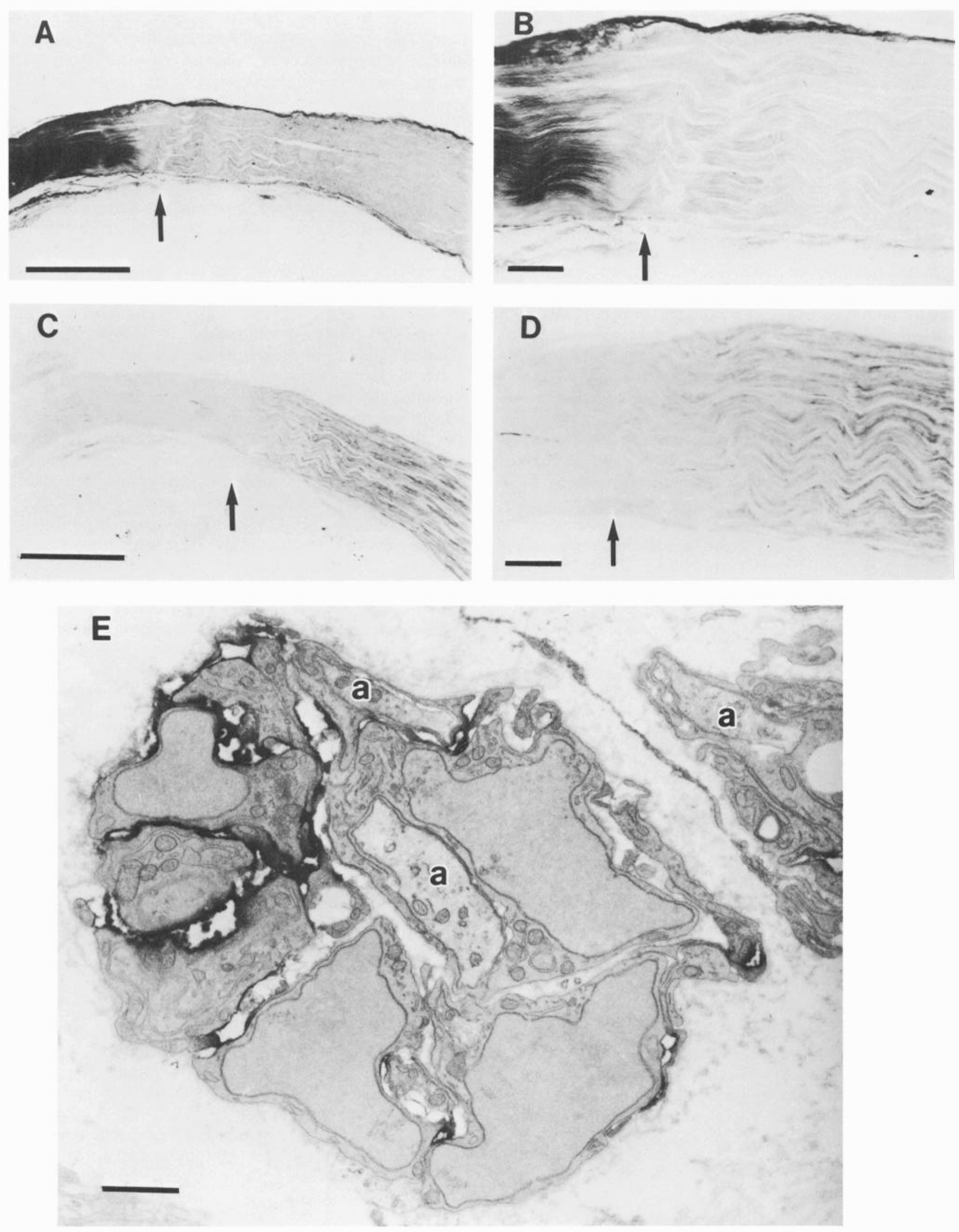

Figure 4. Adjacent longitudinal sections of sciatic nerve, immediately distal to a crush injury, that are stained for axons (Sevier silver stain) and immunostained with 192-IgG to localize NGF receptor. The proximal portion of the nerve (nearest to the crush site) is on the left. The arrows in all sections indicate the same site along the nerve. $A$. Axon stain illustrating the front of regenerating axons $6 \mathrm{~d}$ after crush injury. Scale bar, 250 $\mu \mathrm{m}$. $B$, Higher magnification of $A$ showing that some axons extend beyond the densely stained front present left of the arrow. Scale bar, $50 \mu \mathrm{m}$. $C$, 

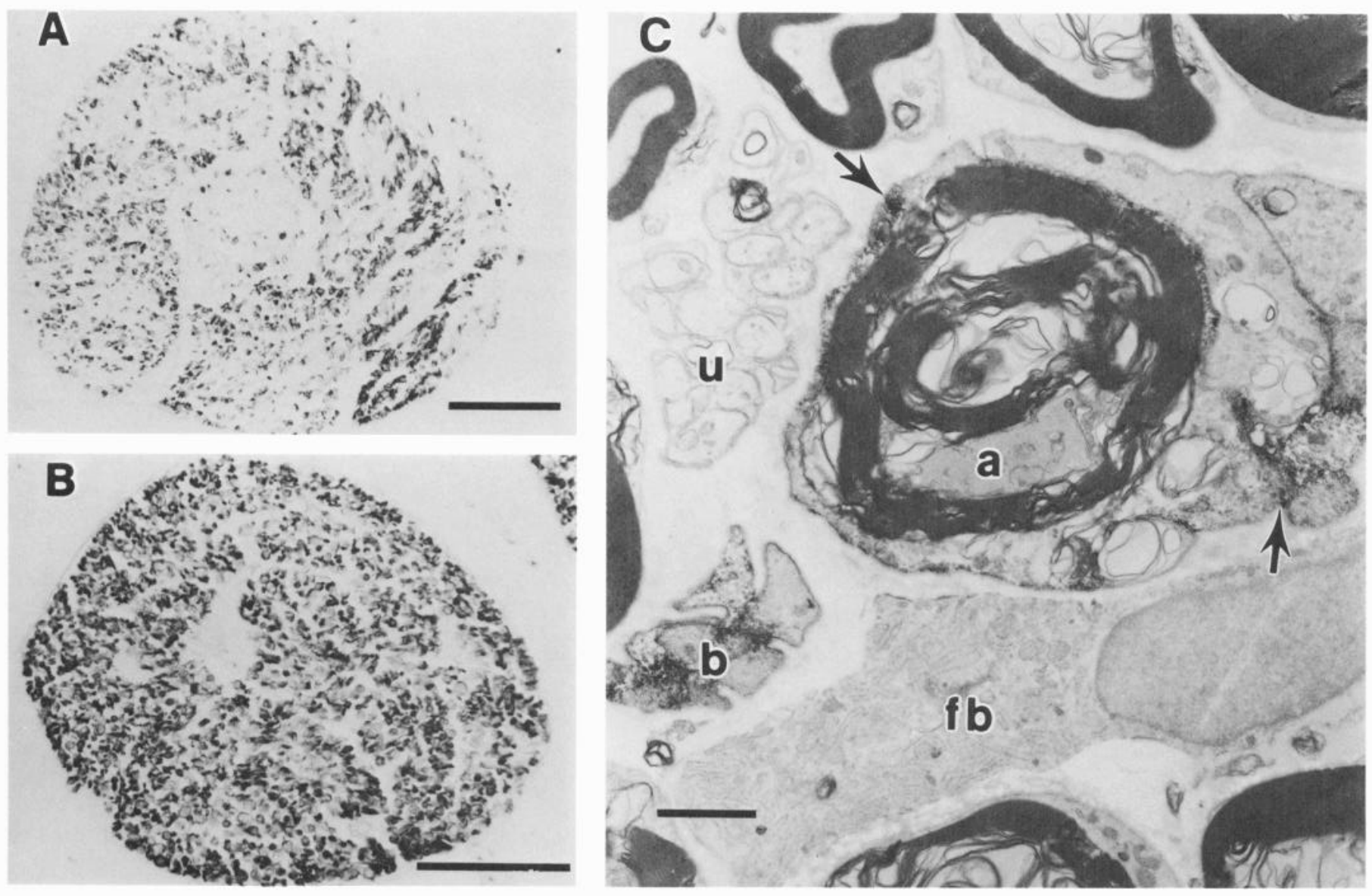

Figure 5. Expression of NGF receptors after $\mathrm{L}_{\mathrm{s}}$ ventral rhizotomy, compared to complete transection of sciatic nerve. $A$, At $14 \mathrm{~d}$ posttransection of the $\mathrm{L}_{5}$ ventral root, some scattered Schwann cells of the sciatic nerve have immunostaining with 192-IgG. These cells are the ones associated with the degenerated motor fibers supplied by the $\mathrm{L}_{5}$ ventral root. $B$, When the sciatic nerve itself is transected, all of the Schwann cells are immunoreactive with 192-IgG after 2 weeks. Scale bars, $50 \mu \mathrm{m}$. C, Electron micrograph of 2 spontaneously degenerating nerve fibers in a control sciatic nerve. There is immunostaining with 192-IgG (arrows) in Schwann cell processes associated with a degenerating myelinated axon (a) and on small bundles of Schwann cell processes $(b)$ that apparently were associated with unmyelinated axons. A fibroblast $(f b)$ and surrounding Schwann cells that are associated with normal myelinated and unmyelinated $(u)$ axons are not immunostained. Scale bar, $1 \mu \mathrm{m}$.

We have postulated that the induction of NGF receptors in Schwann cells is one of a repertoire of mechanisms by which peripheral sheath cells promote axonal regeneration. As a corollary of this hypothesis, the inability of central neuroglia to promote regeneration would be reflected, at least in part, by a lack of NGF receptor induction after axotomy. Until recently, there was no known function of NGF in the CNS; therefore, the lack of NGF receptor induction in the CNS could be deemed irrelevant to the issue of regeneration. However, studies from several investigators have recently shown that NGF is produced in the CNS (Shelton and Reichardt, 1984; Korsching et al., 1985; Goedert et al., 1986; Large et al., 1986; Whittemore et al., 1986), and that specific NGF receptors capable of binding and internalizing the factor are also present in both brain and spinal cord (Richardson and Riopelle, 1984; Seiler and Schwab, 1984; Yip and Johnson, 1984; Richardson et al., 1986; Taniuchi et al., 1986a). Furthermore, NGF appears to exert physiological effects on some populations of neurons, the cholinergic neurons of the median forebrain bundle (Gnahn et al., 1983), and the cholinergic neurons of the striatum (Martinez et al., 1985; Mobley et al., 1985).

We therefore tested the ability of central neuroglia to express NGF receptors in response to axotomy. We chose tracts of neurons known to bear NGF receptors, namely, the dorsal column fibers of the spinal cord (which contain the central processes of NGF receptor-bearing sensory neurons) and the fornix-fimbria tract of the medial septal neurons projecting to the hippocampus. We also examined optic nerve for induction of NGF receptors. The spinal cord was unilaterally double-hemisectioned at the $\mathrm{L}_{4}$ and $\mathrm{L}_{5}$ levels, and 2 weeks later, segments of cord between the lesion sites, as well as segments rostral to the $\mathrm{L}_{4}$ lesion and segments caudal to the $L_{5}$ lesion, were assayed for

Immunostaining of an adjacent section with 192-IgG reveals a reverse pattern, with immunostaining absent where axonal staining is present. Scale bar, $250 \mu \mathrm{m}$. $D$, Higher magnification of $C$ illustrating that in the zone where axonal regeneration has occurred the $192-\mathrm{IgG}$ immunostaining has disappeared. Scale bar, $50 \mu \mathrm{m}$. E. Electron micrograph of sciatic nerve $6 \mathrm{~d}$ after crush injury at a site where axons are reinnervating bands of Bungner. Immunostaining with 192-IgG is intense in some Schwann cell processes but is absent or diminished in processes that have invested regenerating axons $(a)$. Scale bar, $1 \mu \mathrm{m}$. 


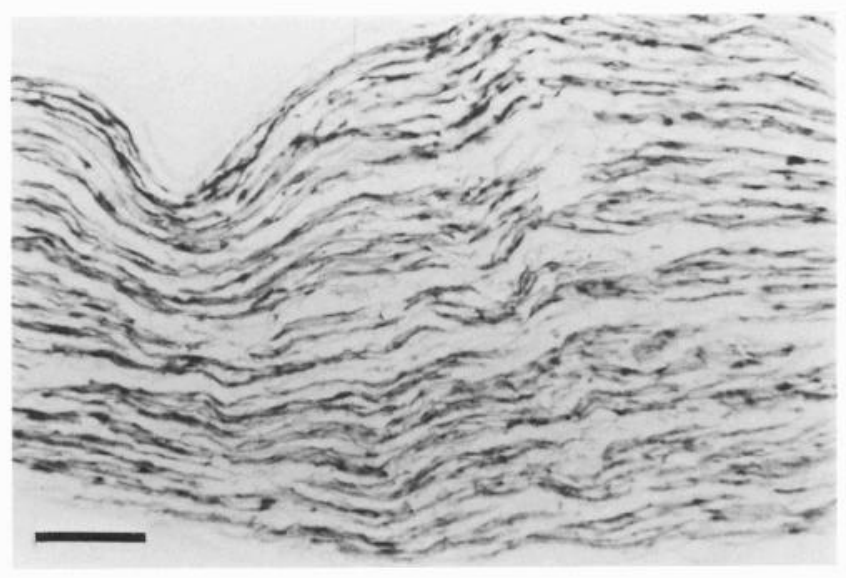

Figure 6. A longitudinal section of the distal segment of vagus nerve 2 weeks after transection shows that virtually all Schwann cells are immunostained with $192-\mathrm{IgG}$. Scale bar, $1 \mu \mathrm{m}$.

their content of NGF receptor. Double-lesioning produces a circumscribed segment that contains degenerating distal segments of both ascending and descending tracts, thereby maximizing the chance of detecting any induction of receptors. In the brain, the fornix-fimbria tract was lesioned bilaterally and, at various time periods, the medial septal region (containing portions of the cholinergic neurons proximal to axotomy) and the hippocampus (containing the distal segments) were dissected, homogenized, and assayed for NGF receptor content. Samples were assayed in parallel for CAT activity, to verify that the fornix-fimbria had been effectively severed. By $4 \mathrm{~d}$ postlesion the CAT activity in samples of hippocampus was reduced to $33 \%$ of control values (data not shown), similar to levels previously reported for fimbria lesions (Lewis et al., 1967). This reduction in CAT activity indicates loss of cholinergic projections. The optic nerve was transected at its junction with the eyeball and the segment peripheral to the optic chiasma was assayed. The results of NGF receptor assay for these CNS experiments are presented in Table 1. There was no increase in the content of NGF receptor distal to axotomy in the spinal cord, brain, or optic nerve. In the segment of spinal cord between the lesion sites, the density of NGF receptor decreased to approximately $30 \%$ of control values, presumably reflecting degeneration of the central processes of sensory neurons. The optic nerve contained no detectable NGF receptors either before or after transection. Therefore, in striking contrast to the Schwann cells of the PNS, the central neuroglial cells appear incapable of increasing their production of NGF receptor molecules in response to axotomy.

\section{Characterization of the binding properties of the induced Schwann cell NGF receptor}

Equilibrium binding of NGF to sympathetic and sensory neurons and to $\mathrm{PC} 12$ cells reveals 2 populations of sites with different apparent affinities: the class I sites $\left(K_{\mathrm{d}}, 20 \mathrm{pm}\right)$ and the class II sites $\left(K_{\mathrm{d}}, 2 \mathrm{~nm}\right)$ (Sutter et al., 1979a; Buxser et al., 1985). Previous studies of the NGF receptors of cultured Schwann cells and ganglionic non-neuronal cells have revealed only class II sites (Sutter et al., 1979b; Carbonetto and Stach, 1982; Zimmerman and Sutter, 1983). We characterized by standard filtration assay the NGF- and 192-IgG-binding properties of the Schwann cell NGF receptors induced in vivo. Figure 7 shows the Scatchard analysis of equilibrium binding of ${ }^{125}$ I-NGF to membrane preparations of superior cervical ganglion (SCG) sympathetic neurons, 14 d-transected distal sciatic nerve, and sciatic nerve from control rats. The plot of SCG membrane binding is curvilinear, consistent with the presence of 2 classes of binding. The apparent affinities are $10 \mathrm{pm}$ and $1.8 \mathrm{~nm}$. In contrast, preparations from transected sciatic nerve showed only a single component of binding, with an apparent affinity of 1.5 nм. Only a very low level of binding was detectable in samples from control sciatic nerve, representing the small amount of receptor being axonally transported (Johnson et al., 1987). These results are consistent with previous findings in cultured Schwann cells from embryonic chickens and rats, and indicate that the NGF receptors induced by axotomy are of the low-affinity form. We also measured the dissociation kinetics of these receptors,

Table 1. Effect of axotomy on NGF receptors of the CNS

${ }^{125} \mathrm{I}-\mathrm{NGF}$ specifically crosslinked (fmol/mg)

\begin{tabular}{lll}
\hline Tract & Control & 14 d postlesion \\
\hline Optic nerve & Not detected & Not detected \\
Spinal cord & $2.48 \pm 0.43(3)$ & \\
Rostral & & $1.17 \pm 0.19(6)$ \\
Middle & & $0.86 \pm 0.06(6)$ \\
Caudal & & $1.40 \pm 0.11(6)$
\end{tabular}

\begin{tabular}{|c|c|c|c|c|c|}
\hline \multirow[b]{2}{*}{ Region } & \multirow[b]{2}{*}{ Control } & \multicolumn{4}{|c|}{ Days postlesion } \\
\hline & & 1 & 4 & 7 & 14 \\
\hline Hippocampus & $0.029(2)$ & $0.028(1)$ & $0.026(2)$ & $0.023(2)$ & $0.026(1)$ \\
\hline $\mathrm{MS} / \mathrm{ndbB}$ & $0.034(2)$ & $0.040(2)$ & $0.048(2)$ & $0.042 \pm 0.002$ & $0.042(2)$ \\
\hline
\end{tabular}

Central axons were lesioned in 3 sites. The spinal cord was double-hemisected in 6 rats at $\mathrm{L}_{4}$ and $\mathrm{L}_{5}$ levels, and 2 weeks later the segment of cord between the lesions (middle), a $1 \mathrm{~cm}$ segment rostral to the $\mathrm{L}_{4}$ lesion (rostral), and a $1 \mathrm{~cm}$ segment caudal to the $\mathrm{L}_{5}$ lesion (caudal) were dissected from each rat. The optic nerve was transected in 6 rats at the junction with the eyeball,and was dissected 2 weeks later. The fornix-fimbria tract was ablated in 11-12 rats, and, at the indicated times, the projection site (hippocampus) and the origin (medial septal nucleus and the nucleus of the diagonal band of Broca, MS/ndbB) of the forebrain cholinergic neurons were dissected. Samples of each tissue were pooled from the population of animals and were assayed for NGF receptor by the ${ }^{125}$ I-NGF crosslinking/192-IgG immunoprecipitation assay. The number in parentheses indicates the number of samples assayed from each pool of tissue. 


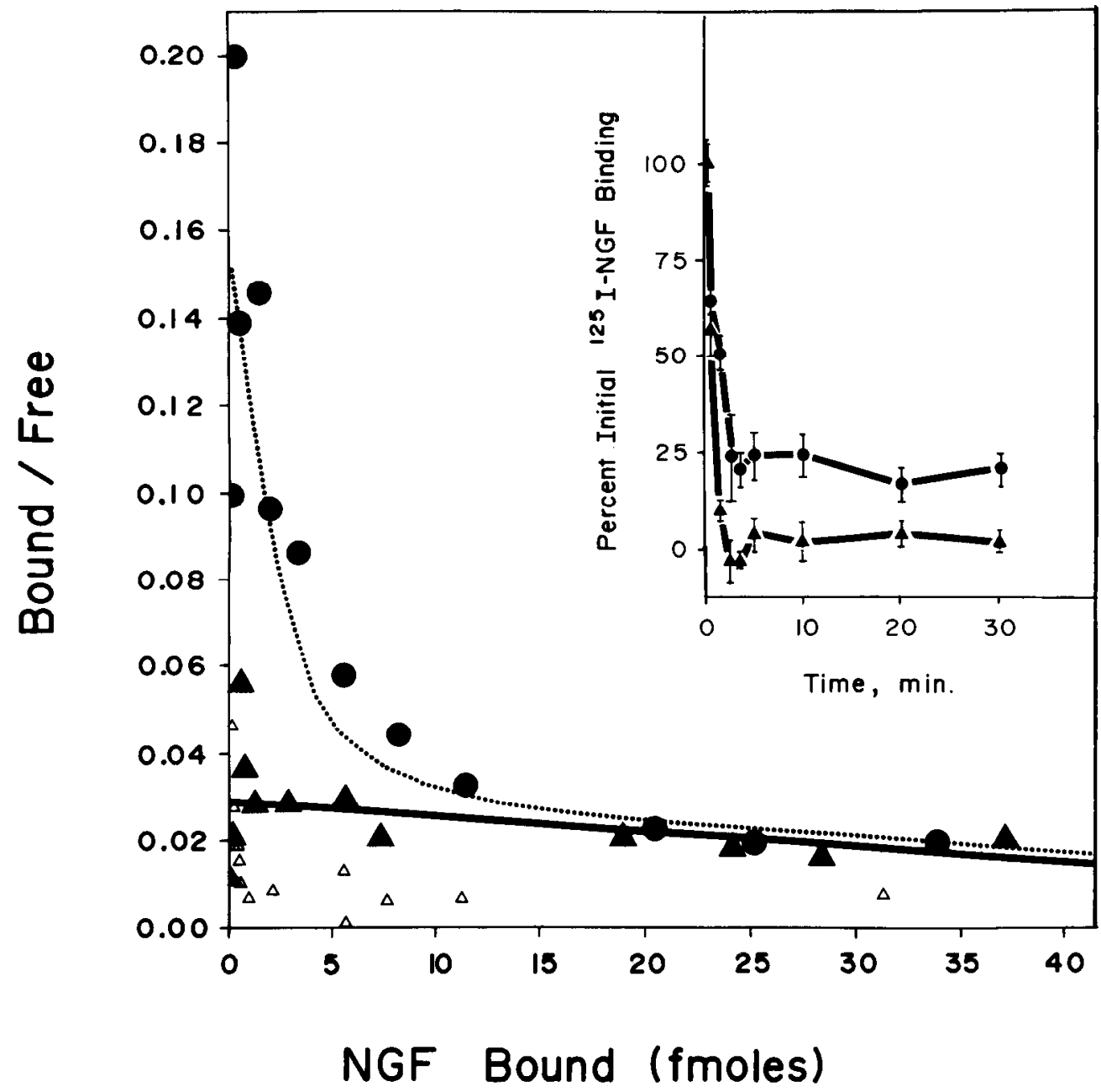

Figure 7. Comparison of the equilibrium binding of ${ }^{225}$ I-NGF to Schwann cell NGF receptors with sympathetic neuronal NGF receptors. Radiolabeled NGF at concentrations ranging from 20 pM to $50 \mathrm{nM}$ were combined with $40 \mu \mathrm{g}$ of $S_{2}$ protein prepared from distal sciatic nerve at $14 \mathrm{~d}$ posttransection (closed triangles), $\mathrm{S}_{2}$ from SCG (closed circles), or $\mathrm{S}_{2}$ from control sciatic nerve (open triangles). After $1.5 \mathrm{hr}$ incubation at $22^{\circ} \mathrm{C}$, the free ${ }^{125} \mathrm{I}-\mathrm{NGF}$ was removed by filtration through Millipore membrane disks. Nonsaturable binding was determined by parallel incubations in the presence of $1 \mu \mathrm{M}$ nonlabeled NGF. All determinations were in triplicate. A Scatchard analysis of the data is shown. The curve was fitted to the data from SCG homogenate in accordance with a quadratic equation describing the binding of a single ligand to 2 independent sites (Feldman, 1972). The line was determined by linear regression to the data from the transected sciatic nerve homogenate. Inset, Dissociation of ${ }^{125}$ INGF from Schwann cell receptors and from sympathetic neuronal receptors. Radiolabeled NGF at 50 pM was incubated with $40 \mu \mathrm{g}$ of $\mathrm{S}_{2}$ protein from transected sciatic nerve (triangles) or from SCG (circles) and allowed to reach equilibrium. Dissociation at $0.4^{\circ} \mathrm{C}$ was initiated by the addition of nonlabeled $\mathrm{NGF}$ to a final concentration of $500 \mathrm{nM}$. At the various time periods, aliquots were filtered through Millipore disks. The data were normalized to the amount of initial binding; the means \pm SEM of triplicate determinations are plotted. and these results are shown in the inset of Figure 7. Membrane preparations from the SCG showed 2 components, a majority $(80 \%)$ of rapidly dissociating sites and a minority $(20 \%)$ of slowly dissociating sites. However, preparations from distal transected nerve showed only rapid dissociation. These results identify the induced Schwann cell NGF receptor as a class II site.

In addition, we examined the equilibrium binding of ${ }^{125}$ I-192IgG to the membrane preparations of control and distal transected nerve. The Scatchard analysis shown in Figure 8 indicates a single binding component with a $K_{\mathrm{d}}$ of $5.2 \mathrm{nM}$. The $192-\mathrm{IgG}$ binding results confirm the increase in receptor density with nerve transection, and the measured dissociation constant matches the previously reported results of ${ }^{125} \mathrm{I}-192-\mathrm{IgG}$ binding to the NGF receptor of PC1 2 cells (Chandler et al., 1984). The inset of Figure 8 shows that ${ }^{125} \mathrm{I}-192-\mathrm{IgG}$ dissociates very slowly from the receptor (virtually no dissociation at $0.4^{\circ} \mathrm{C}$ ). This tight association of the monoclonal antibody allows it to be used effectively as an immunoprecipitation and immunostaining ligand.

\section{Discussion}

We recently reported our observation that surgical transection of rat sciatic nerve induces Schwann cells of the distal nerve to dramatically increase their expression of NGF receptor molecules (Taniuchi et al., 1986b). As the first step in elucidating the biological role of these induced NGF receptors, we sought to define further the conditions in which they are expressed in vivo. In the present study, we have used electron-microscopic immunohistochemistry to localize the receptor molecules to the plasmalemmal surface of Schwann cells. We have shown by biochemical assay and by immunohistochemical examination that the regeneration of axons coincides both temporally and spatially with a reduction in Schwann cell NGF receptor density. Selective axotomy of motoneuronal fibers of the sciatic nerve caused restricted induction of receptor in those Schwann cells ensheathing the degenerating axons, implying that the activating signal is very localized. Ultrastructural examination of regenerating nerves showed that the Schwann cells abutting elongating axons had a reduced density of NGF receptors compared to those not in contact with axonal processes. We have demonstrated that Schwann cells ensheathing axons of NGF-unresponsive neurons, such as lower motoneurons, parasympathetic neurons, and placodally derived sensory neurons, also produce NGF receptor molecules in response to axotomy; the ubiquitous induction suggests strongly that all peripheral sheath cells respond to axonal degeneration by producing NGF receptor, irrespective of the NGF responsiveness of the associated neuron. Axotomy of CNS tracts, including those of NGF-responsive neurons, failed to induce NGF receptor expression in central neuroglia. We have also characterized the binding properties of the induced Schwann cell NGF receptors as low-affinity and fast-dissociating, consistent with class II sites. 
Figure 8. Equilibrium binding of ${ }^{125} \mathrm{I}$ 192-IgG to NGF receptors of Schwann cells and neurons. Radiolabeled 192 $\mathrm{IgG}$ at concentrations ranging from 50 pM to $50 \mathrm{nM}$ was incubated with $40 \mu \mathrm{g}$ of $S_{2}$ protein from distal sciatic nerve at $14 \mathrm{~d}$ posttransection (closed triangles), $\mathrm{S}_{2}$ from SCG (closed circles), or $S_{2}$ from control sciatic nerve (open triangles). After $1.5 \mathrm{hr}$ at $22^{\circ} \mathrm{C}$, the free ${ }^{125}$ I-192-IgG was removed by filtering the samples through Millipore membrane disks. Nonsaturable binding was determined by parallel incubations in the presence of $1 \mu \mathrm{M}$ nonlabeled 192 IgG. All determinations were in triplicate. A Scatchard plot of the data is shown. The line was drawn by linear regression of the data from transected sciatic nerve. Inset, Dissociation of ${ }^{125}$ I192-IgG from Schwann cell NGF receptor. Radiolabeled $192-\mathrm{IgG}$ at $5 \mathrm{nM}$ was combined with $40 \mu \mathrm{g}$ of $\mathrm{S}_{2}$ protein from distal sciatic nerve at $14 \mathrm{~d}$ posttransection and binding was allowed to reach equilibrium. Dissociation at $0.4^{\circ} \mathrm{C}$ was initiated by adding nonlabeled $192-$ IgG to $500 \mathrm{~nm}$. At various times, aliquots were removed and filtered through the Millipore disks. The data were normalized to the amount of initial binding; means \pm SEM of triplicate determinations are plotted.

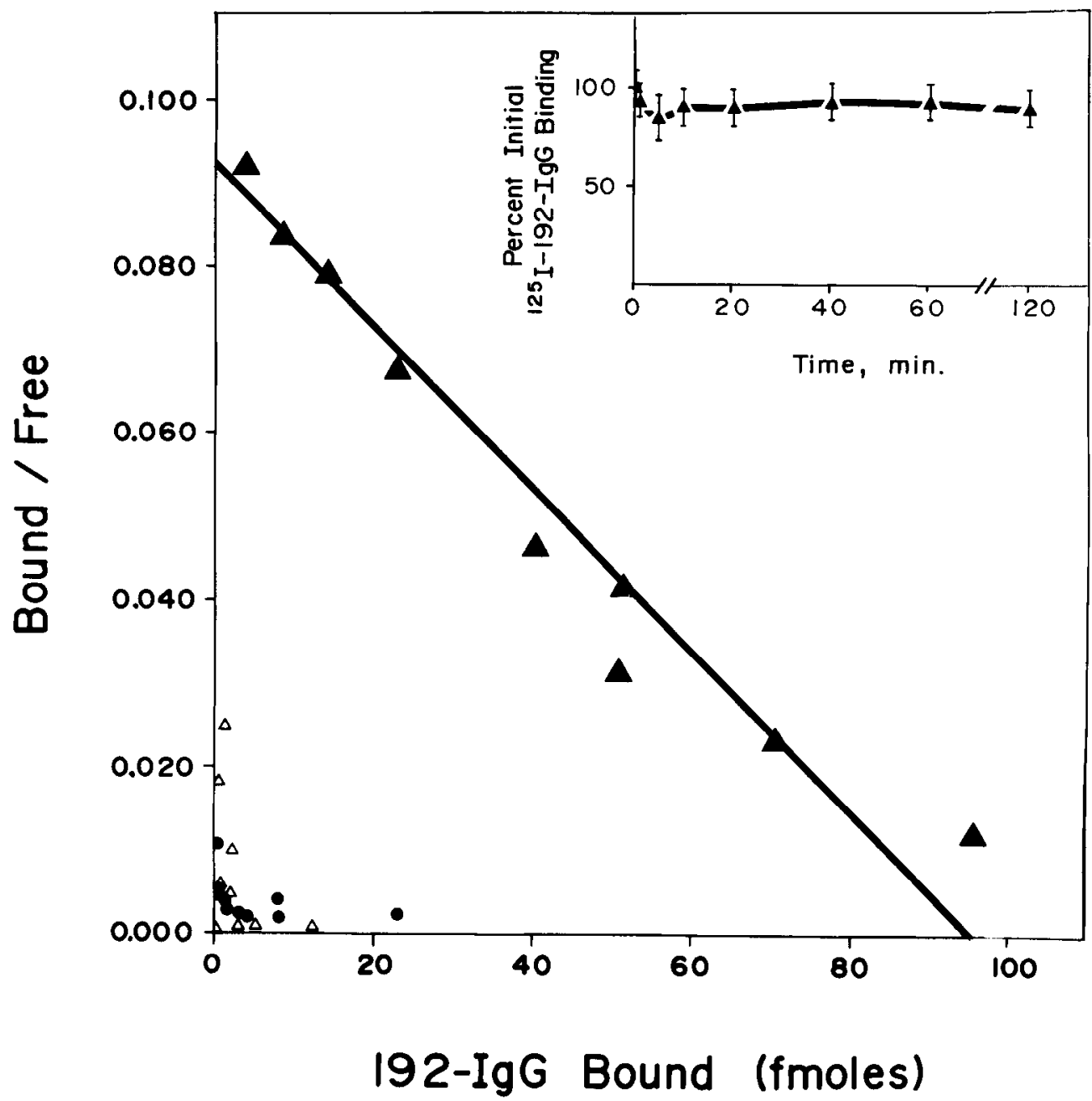

internalize NGF molecules released from the Schwann cell receptors. To test this model, we are currently working to immunostain for NGF in sections of distal transected nerve, with the objective of colocalizing NGF molecules and receptor proteins at the ultrastructural level.

\section{Suppression of Schwann cell NGF receptor expression by axonal regeneration}

The spatial and temporal pattern of NGF receptor induction after nerve transection suggests that receptor expression is part of specific physiological responses of the Schwann cells to the loss of axonal interaction (Taniuchi et al., 1986b). The greatest increase in receptor density occurs in nerves lying distal to the site of axotomy, where the original axons undergo Wallerian degeneration and where the regenerating fibers will eventually migrate. Proximal to the lesion, where the axons remain generally intact, there is only a minor increase in NGF receptor content. The greatest rate of increase in receptor density occurs within the period of 1-3 d postaxotomy, when the distal axons are degenerating. This is also the time when Schwann cells react to the nerve injury by proliferation and phagocytosis of neuronal debris.

Induction of NGF receptor expression in Schwann cells could be mediated by a positive signal, possibly the release of an activating agent from degenerating neuronal elements. Another possibility is that interaction of axons with the investing sheath

\begin{abstract}
the axolemma and Schwann cell plasmalemma are closely jux-
taposed. Those regenerating sympathetic and sensory axons bearing NGF receptors would be optimally situated to bind and

bands of Bungner (Fig. 1). As previously reported (Schwab and Thoenen, 1985), and as shown in Figure 4, the regenerating axons migrate along the surface of these Schwann cells and thus the axolemma and Schwann cell plasmalemma are closely jux-
taposed. Those regenerating sympathetic and sensory axons sory and sympathetic neurons (Taniuchi et al., 1986b). We therefore sought to determine precisely the location of the receptor molecules. We have shown that the majority of receptors are indeed localized on the surface of Schwann cells forming nerves (Rush, 1984; Finn et al., 1986). We have proposed that the function of the injury-induced NGF receptors is to bind and concentrate NGF on the surface of the Schwann cells, thereby providing a substratum laden with haptotactic guidance and trophic support for regenerating axons of NGF-responsive sencan guide axonal growth along the patterns, thereby exerting a haptotactic effect (Gunderson, 1985). Also, Rush and his coworkers have used specific antibodies directed against NGF to
show the presence of NGF on Schwann cells of axotomized

In addition to its trophic effect, NGF has been shown to exert Growth cones will orient toward a gradient of increasing con-
centration of soluble NGF (Gunderson and Barrett, 1980). Furthermore, NGF adsorbed in specific patterns onto a substratum beaning $\mathrm{N}$ F receptors would be optimally situated to bind and
\end{abstract}


cells in intact nerve suppresses NGF receptor production in Schwann cells, and that disruption of the normal interaction during Wallerian degeneration releases the Schwann cells from inhibition of NGF receptor expression. The negative regulation model predicts that Schwann cell expression of NGF receptor would decline temporally and spatially with the progression of regenerating axons. The results presented in this study are consistent with this prediction.

We studied the effects of axonal regeneration on Schwann cell expression of NGF receptor by producing compression lesions on sciatic nerve. Nerve crush with jewelers' forceps axotomizes the neuronal fibers and produces Wallerian degeneration distally, but preserves sufficient continuity of the endoneurium for axons to subsequently regenerate. Nerve crush was effective in inducing the expression of NGF receptors in distal Schwann cells (Figs. 2, 3). Both the biochemical assay and immunohistochemistry detected a dramatic increase in NGF receptor in the first 2 weeks following nerve crush. There appears to be a small quantitative difference between the magnitude of receptor increase following axotomy by crush and that of axotomy by complete transection. It is possible that our protocol of nerve crush resulted in axotomy of fewer fibers than was achieved with transection; examination of distal nerve segments by electron microscopy showed less uniform degeneration of axons following crush lesions than following transection (micrographs not shown).

Immunohistochemical examination of the Schwann cells of distal crushed sciatic nerve at periods beyond 2 weeks postaxotomy showed a progressive decrease with time in the intensity of 192-IgG immunostaining. This diminution correlated with the time course of elongation of regenerating neuronal fibers, as measured crudely by the mechanical stimulation test and by recovery of hindlimb motor function. In both the $2 \mathrm{~cm}$ segment of nerve immediately distal to the crush site and in more distal portions of the nerve contained within the tibialis anterior muscle, the Schwann cells gradually lost immunoreactivity to the NGF receptor, although they showed no morphological signs of atrophy or gross loss of cell number. This decrease in immunoreactivity was also observed by biochemical assay as a decline in NGF receptor content to baseline levels by $70 \mathrm{~d}$ postaxotomy in samples of both nerve segments and muscle.

In the absence of axonal regeneration (i.e., after sciatic nerve transection), Schwann cells of the distal nerve segment and muscle continued to show strong immunostaining with $192-\mathrm{IgG}$, but were reduced in volume and number. At dissection, the distal segment of nerve showed considerable atrophy by 5 weeks posttransection, and by 10 weeks it was attenuated to the point of being translucent. The muscles were also significantly atrophied. The reason for the observed difference in receptor density between muscle samples and nerve segment in the transected rats is unclear. Part of the discrepancy may arise simply from normalizing the NGF receptor content to the amount of protein in the sample. By this method, $\mathbf{S}_{2}$ fractions (containing equal amounts of total protein) prepared from atrophied muscles would represent the contribution of more individual muscles and the nerves contained within them than those prepared from normal muscles. On the other hand, the difference between nerve and muscle samples may reflect a differential loss of Schwann cells with time, such that cells are lost from the more central portion of the distal stump first and remain longest in the more peripheral portions contained within muscle tissue.

Immunohistochemical examination provided a clear picture of the spatial relationship between axonal regeneration and the reduction in Schwann cell NGF receptor expression. Silverstaining for axonal neurofibrils and immunostaining with 192IgG in adjacent tissue sections of distal crushed nerve showed an inverse relationship between the presence of neuronal fibers and the density of NGF receptor on Schwann cells (Fig. 4). Within the region of nerve through which axons had regenerated, the Schwann cells showed virtually no immunostaining with 192-IgG. At the border of advancing axons there was minimally detectable immunoreactivity. As the density of axons decreased toward the periphery, the intensity of receptor immunostaining increased in a reciprocal manner over a distance of roughly $0.5-1.0 \mathrm{~mm}$. Because the mechanical stimulation assay measured sensory fiber growth of approximately $2.4 \mathrm{~mm} /$ $\mathrm{d}$, we estimate that loss of Schwann cell NGF receptors at the front of regencrating axons occurs in less than $12 \mathrm{hr}$.

Ultrastructural examination of the axonal regeneration front showed individual differences in Schwann cell immunostaining, dependent on association with regenerating axons. Those Schwann cells clearly making contact with neuronal processes exhibited diminished or absent NGF receptor immunoreactivity. Other Schwann cells in the same transverse section that were devoid of axonal contact showed intense immunoreactivity. These results suggest a very stringent and localized regulation by neuronal elements of Schwann cell NGF receptor production. The observation that Schwann cells situated within several microns of each other exhibit such prominent differences in receptor density suggests that neurons suppress NGF receptor expression in Schwann cells by axolemmal contact, not by a diffusible agent. Results of selective axotomy, discussed in the next section, further support this hypothesis. A few Schwann cells that did not appear to abut any neuronal elements within the plane of section of the micrograph also showed diminished immunoreactivity. It is likely that NGF receptor expression in these cells had already been suppressed by axonal contact located outside the plane of section.

\section{Induction of NGF receptor in Schwann cells ensheathing neurons that are unresponsive to NGF}

The ubiquitous induction of NGF receptor molecules on Schwann cells implies that even those Schwann cells ensheathing axons of neurons that do not respond to NGF, such as motoneurons, are capable of expressing NGF receptors in response to axonal injury. We therefore tested for receptor induction after selectively axotomizing motoneurons of the sciatic nerve by ventral rhizotomy, and after transecting the vagus nerve. In both cases, Wallerian degeneration resulted in the appearance of $192-$ IgG immunoreactivity in the associated Schwann tubes (Figs. $4 E, 5 C$ ). It appears, therefore, that production of NGF receptors, and presumably of NGF, is part of a general activation pattern of Schwann cells in response to neuronal damage. We speculate that this activation also involves the production of other trophic agents, as yet uncharacterized, which act on motoneurons and parasympathetic neurons.

The restricted pattern of NGF receptor induction in Schwann cells observed after selective ventral rhizotomy (Fig. $5 \mathrm{~A}$ ) and in spontaneous axonal degeneration of restricted fibers (Fig. $5 \mathrm{C}$ ) argues against induction by a diffusible inducing agent, which would be expected to exert effects over a wider area. Moreover, the fact that axonal degeneration of NGF-unresponsive motoneurons can induce Schwann cell NGF receptor expression precludes the possibility that the ubiquitous induction seen after 
complete nerve transection is caused by an agent released only from degenerating NGF-responsive neurons. The results seen in regenerating nerve suggest that regulation of Schwann cell NGF receptor expression involves suppression by axolemmal contact. The sustained expression of NGF receptors by Schwann cells months after initial induction would also seem more consistent with removal of an inhibitory influence than with a continuous stimulating signal. Furthermore, when Schwann cells are isolated from neuronal fibers and placed into tissue culture, they show increase in NGF receptor with a time course similar to that observed in vivo (DiStefano and Johnson, 1988), again suggesting that removal of axonal contact releases inhibition of NGF receptor expression.

\section{Absence of $N G F$ receptor induction in central neuroglia}

Numerous studies have shown that CNS tissue fails to support axonal regeneration after injury, but that peripheral nerve can promote elongation of central axons (Richardson et al., 1980, 1984; David and Aguayo, 1981; Benfey and Aguayo, 1982). Much evidence implicates the inability of central neuroglia to provide a suitable environment as the basis of this difference. Whereas Schwann cells form bands of Bungner through which regenerating axons migrate, astrocytes of the CNS form a glial scar that appears to block the progress of growth cones. We speculated that the difference between peripheral and central regenerative capacities would be reflected in the capacities of Schwann cells and central neuroglia to induce expression of NGF receptors following axotomy. The results presented in Table 1 confirm this prediction: There was no induction of NGF receptor after lesions of the spinal cord, the fornix-fimbria, or the optic nerve. The first 2 sites of lesions contain tracts of neurons that have been shown to bear NGF receptors and to respond to NGF. Therefore, mechanisms to promote regeneration of these axons, if they exist, might be expected to involve the induction of NGF receptors. The failure of astrocytes and oligodendroglia to increase their expression of NGF receptors reflects a fundamental difference between central and peripheral neuroglia. These data clearly show that a generalized response of CNS glial cells, analogous to that of Schwann cells, does not occur. These results would not preclude a subpopulation of glia becoming NGF receptor-positive. This seems unlikely, since immunohistochemical examination of CNS tissues in our and other laboratories (L. F. Kromer, unpublished observations; C. N. Montero and F. Hefti, unpublished observations) have failed to detect any such population. Schwann cells of the PNS have the capacity to provide a suitable substratum for migration of regenerating axons, including the production of trophic/tropic agents, but astrocytes and oligodendrocytes appear to lack the repertoire of cellular responses necessary to support axonal regeneration. The failure of CNS glia to express NGF receptor may be one of several differences between CNS glia and Schwann cells that account for the superior ability of Schwann cells to support axonal growth.

\section{Binding of NGF and 192-IgG to induced Schwann cell NGF receptors}

Filtration assays performed on plasma membrane-enriched preparations of sciatic nerve distal to transection yielded a linear Scatchard plot of ${ }^{125}$ I-NGF binding with an apparent dissociation constant of $1.5 \mathrm{nM}$. In contrast to results obtained with membrane preparations of SCG, which contain NGF receptors of sympathetic neuronal somata, no class I sites were detected in the distal nerve stump. The assays measuring ${ }^{125}$ I-NGF dissociation kinetics showed only a single, rapidly dissociating component in preparations of distal nerve stump. These results demonstrate that the Schwann cell NGF receptors induced in vivo are class II binding sites. Previous studies of NGF binding to cultured embryonic Schwann cells have also reported equilibrium binding results consistent with class II sites (Zimmermann and Sutter, 1983). Furthermore, Schwann cells separated from axons and placed into tissue culture also show increases in NGF binding with time, and these NGF-binding sites show the low-affinity, fast-dissociation characteristics of class II sites (DiStefano and Johnson, 1988).

Binding of ${ }^{125} \mathrm{I}-192-\mathrm{IgG}$ to a membrane prepartion of sciatic nerve distal to transection yielded a linear Scatchard plot with an apparent $K_{\mathrm{d}}$ of $5.2 \mathrm{nM}$. This is consistent with the previously reported dissociation constant (5 nM) of ${ }^{125}$ I-192-IgG binding to PC12 cells (Chandler et al., 1984). The number of ${ }^{125}$ I-192IgG binding sites in membrane preparations of transected nerve was approximately 18 -fold greater than the number of sites in preparations of control sciatic nerve. Because of the extremely slow dissociation of $192-\mathrm{IgG}$, direct binding of ${ }^{125} \mathrm{I}-192-\mathrm{IgG}$ appears to be the most accurate means currently available for quantitating absolute numbers of NGF receptor molecules. Filtration binding of ${ }^{125} \mathrm{I}-\mathrm{NGF}$ greatly underestimates the number of low-affinity sites because a significant fraction of bound radioligand dissociates from the receptor during the wash procedure. The ${ }^{125}$ I-NGF crosslinking/192-IgG immunoprecipitation assay requires multiple binding reactions and therefore quantitative recovery is impossible. Nevertheless, the relative densities of NGF receptor of different samples are very similar when determined by either the crosslinking/immunoprecipitation assay or the ${ }^{125}$ I-192-IgG filtration assay. The magnitude of NGF receptor induction after sciatic nerve transection is approximately 20 -fold, measured by either method.

\section{Physiological significance of Schwann cell NGF receptors}

Numerous studies have shown that Schwann cells are capable of promoting axonal regeneration of both peripheral and central neurons (Richardson ct al., 1980, 1984; David and Aguayo, 1981; Benfey and Aguayo, 1982; Kromer and Cornbrooks, 1986). Our finding that these cells respond to axonal injury by producing NGF receptors raises the possibility that the potent trophic and tropic effects of NGF are involved in the process of peripheral nerve regeneration. This proposition is strengthened by recent reports of NGF production in segments of nerve distal to the site of axotomy (Korsching et al., 1986). It is unlikely that the Schwann cells express NGF receptor in order to use NGF in an autocrine or paracrine manner, because Schwann cells do not internalize NGF (DiStefano and Johnson, 1988) and show no detectable biological responses to the agent. On the other hand, it has been demonstrated that both soluble NGF (Gunderson and Barrett, 1980) and substrate-adsorbed NGF (Gunderson, 1985) can attract and guide the migration of regenerating sensory axons in tissue culture. Therefore, NGF produced in distal portions of an injured nerve could profoundly influence the peripheral outgrowth of regenerating sensory and sympathetic axons.

Our working hypothesis of the biological function of the Schwann cell NGF receptors is presented schematically in Figure 9 . Axotomy caused by trauma to the nerve leads to Wallerian degeneration of the fibers distal to the injury; consequently, the neurons are cut of from the supply of trophic factor produced 


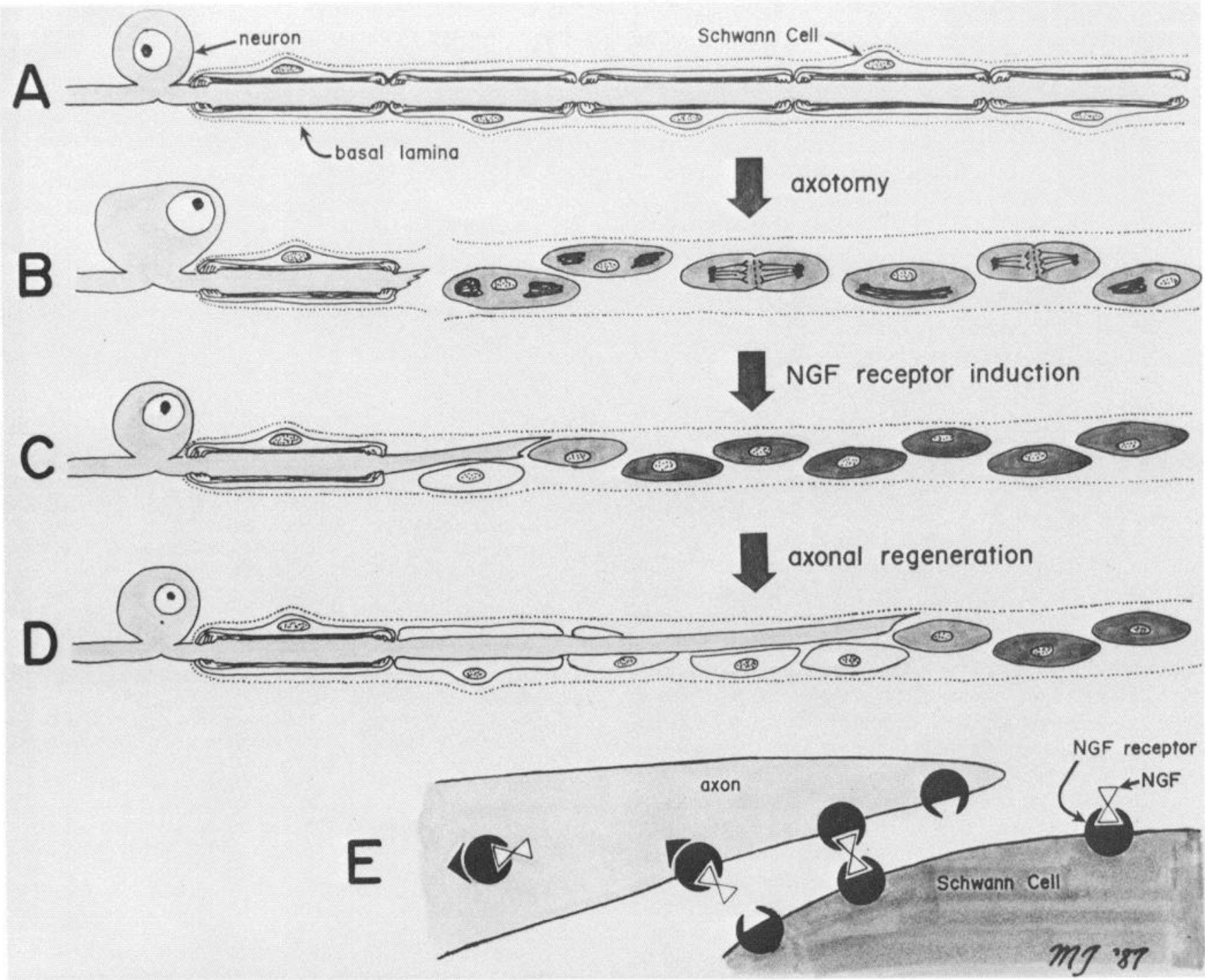

Figure 9. Model of Schwann cell production of NGF and NGF receptor in peripheral nerve regeneration. $A$, An intact peripheral sensory neuron with its axon ensheathed by myelinating Schwann cells. The NGF receptor density of the neuron is indicated by the light shading. B, Axotomy leads to Wallerian degeneration of the distal axon and phagocytosis of neuronal elements and myelin debris by Schwann cells. The Schwann cells proliferate by mitosis, and are activated to produce NGF receptors, as indicated by the shading. $C$, In a week's time, the Schwann cells of the distal nerve segment have maximal levels of NGF receptor expression, as indicated by the dark shading. Axonal elongation has begun, the growth cone moving over the Schwann cell surface. Those Schwann cells that the axon has contacted show reduced levels of NGF receptor. $D$, With continued axonal elongation, Schwann cell NGF receptor expression decreases from a central to peripheral direction. The Schwann cells located most centrally begin to ensheathe the regenerated axon. $E$, Detail of the growth cone, showing the receptor-mediated intercellular transfer of NGF from the Schwann cell to the axon. The class I sites of the axon bind NGF released from the class II sites of the Schwann cell and internalize the NGFNGF receptor complex. The NGF and NGF receptor proteins are retrogradely transported through the axon to the somata.

by the target organ. The Schwann cells ensheathing the dying axons are stimulated to proliferate, phagocytose the neuronal debris, and form bands of Bungner (Abercrombie and Johnson, 1946; Payer, 1979). Concurrently, the loss of axolemmma induces the Schwann cells to express on their plasma membrane surface the class II NGF receptor proteins and to produce and release NGF molecules. The NGF binds to the receptor and thereby becomes concentrated upon the Schwann cell surface. As regenerating axons of sensory and sympathetic neurons enter the distal portion of nerve, they are guided haptotactically along the Schwann cell substratum by the binding of NGF to their own NGF receptors. The class I NGF receptors on the axolem$\mathrm{ma}$, by virtue of their slow-dissociation binding characteristic, can bind and retain NGF molecules as they are released from the fast-dissociating class II receptors of the Schwann cells. The close apposition of regenerating axolemma and Schwann cell plasmalemma would facilitate the receptor-mediated, intercellular transfer of NGF. The neuronal receptors internalize NGF, which is subsequently retrogradely transported to provide trophic support for the regenerating axon while it is growing through the distal nerve; the Schwann cell-derived NGF thereby substitutes for end organ-derived NGF during axonal elongation. Concurrently, axolemmal contact acts to suppress Schwann cell expression of NGF receptor and NGF. With continued elongation of the regenerating axons and concomitant Schwann cell suppression, a dynamic gradient is established, with the most highly activated Schwann cells located distally. The resultant gradient of substrate-adsorbed NGF maintains the proper di- 
rectionality of axonal regeneration. When the neuronal fibers reinnervate the target organs, these tissues again become the source of NGF, while the Schwann cells return to a quiescent state.

We speculate that Schwann cells are activated by Wallerian degeneration of the associated axons to produce not only NGF and its receptor, but also other agents with neurotrophic or neurotropic activity toward other neuronal cell types, such as motoneurons. The production of such substances in response to axonal injury could explain the phenomenon in which an initial "conditioning lesion" of a peripheral nerve results in enhanced axonal regeneration after a second injury (McQuarrie, 1978). The conditioning lesion would initiate Schwann cell activation, and therefore the production of the neurotrophic and neurotropic agents would already be elevated by the time of the second injury.

It is possible that a similar interaction functions during development, when axons and Schwann cells migrate together to the periphery. NGF-binding sites have been detected on nonneuronal cells in embryonic chickens (Rohrer and Sommer, 1983; Raivich et al., 1985; Rohrer, 1985). Even prior to innervation of target tissue, neurons may be dependent on paracrine growth factors and Schwann cells may provide the growing axons with these necessary factors during the period of outgrowth. While peripheral growth is occurring, the interaction between Schwann cells and axons matures, and Schwann cell production of the trophic factors decreases. The neurons thereby become increasingly dependent on trophic agents released by the target tissue for survival and continued development. As the growth cones reach the target tissue, the primary source of the trophic agents shifts from the Schwann cells to the cells of the end organ. Thus, the development of neuronal dependence on target tissue observed experimentally may not reflect a switch of the neurons from a trophic factor-independent phenotype to a trophic factordependent one; rather, the neurons may be responsive to trophic agents from their genesis, but the source of these agents changes from the Schwann cell to the target tissue during peripheral nerve development.

\section{References}

Abercrombie, M., and M. L. Johnson (1946) Quantitative histology of Wallerian degeneration. I. Nuclear population in rabbit sciatic nerve. J. Anat. 80: 37-50.

Aguayo, A. J., M. Benfey, and S. David (1983) A potential for axonal regeneration in neurons of the adult mammalian nervous system. In Nervous System Regeneration, B. Haber, J. R. Perez-Polo, G. A. Hashim, and A. M. G. Stella, eds., pp. 327-340, Liss, New York.

Benfey, M., and A. J. Aguayo (1982) Extensive elongation of axons from rat brain into peripheral nerve grafts. Nature 296: 150-152.

Bernd, P., and L. A. Greene (1984) Association of ${ }^{225}$ l-nerve growth factor with PC12 pheochromocytoma cells. Evidence for internalization via high-affinity receptors only and long-term regulation by nerve growth factor of both high- and low-affinity receptors. J. Biol. Chem. 259: 15509-15516.

Bocchini, V., and P. U. Angeletti (1969) The nerve growth factor: Purification as a 30,000 molecular weight protein. Proc. Natl. Acad. Sci. USA 64: 787-794.

Buxser, S. E., P. Puma, and G. L. Johnson (1985) Purification and properties of the nerve growth factor receptor. In Biochemical Actions of Hormones, vol. 12, G. Litwack, ed., pp. 433-456, Academic, New York.

Carbonetto, S., and R. W. Stach (1982) Localization of nerve growth factor bound to neurons growing nerve fibers in culture. Dev. Brain Res. 3: 463-473.

Chandler, C. E., L. M. Parsons, M. Hosang, and E. M. Shooter (1984) A monoclonal antibody modulates the interaction of nerve growth factor with PC12 cells. J. Biol. Chem. 259: 6882-6889.
Chandler, L. P., C. Chandler, M. Hosang, and E. M. Shooter (1985) A monoclonal antibody which inhibits epidermal growth factor binding has opposite effects on the biological action of epidermal growth factor in different cells. J. Biol. Chem. 260: 3360-3367.

Costrini, N. Y., and R. A. Bradshaw (1979) Binding characteristics and apparent molecular size of detergent-solubilized nerve growth factor receptor of sympathetic ganglia. Proc. Natl. Acad. Sci. USA 76: 3242-3245.

David, S., and A. J. Aguayo (1981) Axonal elongation into peripheral nervous system "bridges" after central nervous system injury in adult rats. Science 214: 931-933.

DiStefano, P. S., and E. M. Johnson, Jr. (1988) Nerve growth factor receptors on cultured rat Schwann cells. J. Neuroscience 8: 231-241.

Feldman, H. A. (1972) Mathematical theory of complex ligand-binding systems at equilibrium: Some methods for parameter fitting. Anal. Biochem. 48: 317-338.

Finn, P. J., I. A. Ferguson, F. J. Renton, and R. A. Rush (1986) Nerve growth factor immunohistochemistry and biological activity in the rat iris. J. Neurocytol. 15: 169-176.

Gnahn, H., F. Hefti, R. Heumann, M. E. Schwab, and H. Thoenen (1983) NGF-mediated increase of choline acetyltransferase (ChAT) in the neonatal rat forebrain: Evidence for a physiological role of NGF in the brain? Dev. Brain Res. 9: 45-52.

Goedert, M., A. Fine, S. P. Hunt, and A. Ullrich (1986) Nerve growth factor messenger-RNA in peripheral and central rat tissues and in the human central nervous system: Lesion effects in the rat brain and levels in Alzheimer's disease. Mol. Brain Res. 1: 85-92.

Gunderson, R. W. (1985) Sensory neurite growth cone guidance by substrate adsorbed nerve growth factor. J. Neurosci. Res. 13: 199212.

Gunderson, R. W., and J. N. Barrett (1980) Characterization of the turning response of dorsal root neurites toward nerve growth factor. J. Cell Biol. 87: 546-554.

Hefti, F. (1986) Nerve growth factor promotes survival of septal cholinergic neurons after fimbrial transections. J. Neurosci. 6: 21552162.

Hefti, F., and W. J. Weiner (1986) Nerve growth factor and Alzheimer's disease. Ann. Neurol. 20: 275-281.

Hendry, I. A., K. Stockel, H. Thoenen, and L. L. Iversen (1974) The retrograde axonal transport of nerve growth factor. Brain Res. 68 103-121.

Honegger, P., and D. Lenoir (1982) Nerve growth factor (NGF) stimulation of cholinergic telencephalic neurons in aggregating cell cultures. Dev. Brain Res. 3: 229-238.

Johnson, E. M., Jr., K. M. Rich, and H. K. Yip (1986) The role of NGF in sensory neurons in vivo. Trends Neurosci. 9: 33-37.

Johnson, E. M., Jr., M. Taniuchi, H. B. Clark, J. E. Springer, S. Y. Koh, M. W. Tayrien, and R. Loy (1987) Demonstration of the retrograde transport of nerve growth factor receptor in peripheral and central nervous system. J. Neurosci. 7: 923-929.

Korsching, S., and $H$. Thoenen (1983a) Nerve growth factor in sympathetic ganglia and corresponding target organs of the rat: Correlation with density of sympathetic innervation. Proc. Natl. Acad. Sci. USA 80: 3513-3516.

Korsching, S., and H. Thoenen (1983b) Quantitative demonstration of the retrograde axonal transport of endogenous nerve growth factor. Neurosci. Lett. 39: 1-4.

Korsching, S. I., G. Auberger, R. Heumann, J. Scott, and H. Thoenen (1985) Levels of nerve growth factor and its mRNA in the central nervous system of the rat correlate with cholinergic innervation. EMBO J. 4: 1389-1393.

Korsching, S. I., R. Heumann, A. Davies, and H. Thoenen (1986) Levels of nerve growth factor and its mRNA during development and regeneration of the peripheral nervous system. Soc. Neurosci. Abstr. 12: 1096.

Kromer, L. F., and C. J. Cornbrooks (1986) Transplants of Schwann cell cultures promote axonal regeneration in the adult mammalian brain. Proc. Natl. Acad. Sci. USA 82: 6330-6334.

Laemmli, U. K. (1970) Cleavage of structural proteins during the assembly of the head of bacteriophage T4. Nature 227: 680-685.

Landreth, G. E., and E. M. Shooter (1980) Nerve growth factor receptors on PC1 2 cells: Ligand-induced conversion from low- to highaffinity states. Proc. Natl. Acad. Sci. USA 8: 4751-4755.

Large, T. H., S. C. Bodary, D. O. Clegg, G. Weskamp, U. Otten, and L. F. Reichardt (1986) Nerve growth factor gene expression in the developing rat brain. Science 234: 352-355. 
Lewis, P. R., C. C. D. Shute, and A. Silver (1967) Confirmation from choline acetylase analyses of a massive cholinergic innervation to the rat hippocampus. J. Physiol. 191: 215-224.

Lowry, O. H., N. J. Rosebrough, A. L. Farr, and R. J. Randall (1951) Protein measurement with the Folin phenol agent. J. Biol. Chem. 193: 265-275.

Marchalonis, J. J. (1969) An enzyme method for the trace iodination of immunoglobulins and other proteins. Biochem. J. 113: 299-305.

Martinez, H. J., C. F. Dreyfus, G. M. Jonakait, and I. B. Black (1985) Nerve growth factor promotes cholinergic development in brain striatal cultures. Proc. Natl. Acad. Sci. USA 82: 7777-7781.

McQuarrie, I. G. (1978) The effect of a conditioning lesion on the regeneration of motor axons. Brain Res. 152: 597-602.

Mobley, W. C., J. L. Rutkowski, G. I. Tennekoon, K. Buchanan, and M. V. Johnston (1985) Choline acetyltransferase activity in striatum of neonatal rats increased by nerve growth factor. Science 229: 284287.

Palmatier, M. A., B. K. Hartman, and E. M. Johnson, Jr. (1984) Demonstration of retrogradely transported endogenous nerve growth factor in axons of sympathetic neurons. J. Neurosci. 4: 751-756.

Payer, A. F. (1979) An ultrastructural study of Schwann cell response to axonal degeneration. J. Comp. Neurol. 183: 365-384.

Purves, D., and J. W. Lichtman (1985) Principles of Neural Development, Sinauer, Sunderland, MA.

Raivich, G., A. Zimmermann, and A. Sutter (1985) The spatial and temporal pattern of $\beta$ NGF receptor expression in the developing chick embryo. EMBO J. 4: 637-644.

Rich, K. M., and E. M. Johnson, Jr. (1985) Ventral rhizotomy enhances regeneration of uninjured sensory neurons. Brain Res. 335: 182-187.

Richardson, P. M., and R. J. Riopelle (1984) Uptake of nerve growth factor along peripheral and spinal axons of primary sensory neurons. J. Neurosci. 4: 1683-1689.

Richardson, P. M., U. M. Mcguinness, and A. J. Aguayo (1980) Axons from CNS neurones regenerate into PNS grafts. Nature 284: 264 265.

Richardson, P. M., V. M. K. Issa, and A. J. Aguayo (1984) Regeneration of long spinal axons in the rat. J. Neurocytol. 13: 165-182.

Richardson, P. M., V. M. K. Verge Issa, and R. J. Riopelle (1986) Distribution of neuronal receptors for nerve growth factor in the rat. J. Neurosci. 6: 2313-2321.

Rohrer, H. (1985) Nonneuronal cells from chick sympathetic and dorsal root sensory ganglia express catecholamine uptake and receptors for nerve growth factor during development. Dev. Biol. 111:95107.

Rohrer, H., and I. Sommer (1983) Simultaneous expression of neuronal and glial properties by chick ciliary ganglion cells during development. J. Neurosci. 3: 1683-1693.

Rush, R. A. (1984) Immunohistochemical localization of endogenous nerve growth factor. Nature 312: 364-367.

Schrier, B. K., and L. Schuster (1967) A simplified radiochemical assay for choline acetyltransferase. J. Neurochem. 14: 977-985.

Schwab, M. E., and H. Thoenen (1985) Dissociated neurons regenerate into sciatic but not optic nerve explants in culture irrespective of neurotrophic factors. J. Neurosci. 5: 2415-2423.

Seiler, M., and M. E. Schwab (1984) Specific retrograde transport of nerve growth factor (NGF) from neocortex to nucleus basalis in the rat. Brain Res. 300: 33-39.
Sevier, A. C., and B. L. Munger (1965) Technical note: A silver method for paraffin sections of neural tissue. J. Neuropathol. Exp. Neurol. 24: $130-135$.

Shelton, D. L., and L. F. Reichardt (1984) Expression of the $\beta$-nerve growth factor gene correlates with the density of sympathetic innervation in effector organs. Proc. Natl. Acad. Sci. USA 81: 7951-7955.

Shelton, D. L., and L. F. Reichardt (1986) Studies on the expression of the $\beta$ nerve growth (NGF) gene in the central nervous system: Level and regional distribution of NGF mRNA suggests that NGF functions as a trophic factor for several distinct populations of neurons. Proc. Natl. Acad. Sci. USA 83: 2714-2718.

Smithson, K. G., B. A. MacVicar, and G. I. Hatton (1983) Polyethylene glycol embedding: A technique compatible with immunocytochemistry, enzymc histochemistry, histofluorescence, and intracellular staining. J. Neurosci. Methods 7: 27-41.

Spurr, A. R. (1969) A low viscosity epoxy resin embedding medium for electron microscopy. J. Ultrastruct. Res. 26: 32-42.

Sutter, A., R. J. Riopelle, R. M. Harris-Warrick, and E. M. Shooter (1979a) The heterogeneity of nerve growth factor receptors. In Transmembrane Signaling, Progress in Clinical Biological Research. M. Bitensky, R. J. Collier, D. F. Steiner, and F. C. Fox, eds., pp. 659667, Liss, New York.

Sutter, A., R. J. Riopelle, R. M. Harris-Warrick, and E. M. Shooter (1979b) Nerve growth factor receptors. Characterization of two distinct classes of binding sites on chick embryo sensory ganglia cells. J. Biol. Chem. 254: 5972-5982.

Taniuchi, M., and E. M. Johnson, Jr. (1985) Characterization of the binding properties and retrograde axonal transport of a monoclonal antibody directed against the rat nerve growth factor receptor. J. Cell Biol. 101: 1100-1106.

Taniuchi, M., J. B. Schweitzer, and E. M. Johnson, Jr. (1986a) Nerve growth factor receptor molecules in rat brain. Proc. Natl. Acad. Sci. USA 83: 1950-1954.

Taniuchi, M., H. B. Clark, and E. M. Johnson, Jr. (1986b) Induction of nerve growth factor receptor in Schwann cells after axotomy. Proc. Natl. Acad. Sci. USA 83: 4094-4098.

Thoenen, H., and Y.-A. Barde (1980) Physiology of nerve growth factor. Physiol. Rev. 60: 1284-1335.

Vale, R. D., M. J. Ignatius, and E. M. Shooter (1985) Association of nerve growth factor receptors with the Triton X-100 cytoskeleton of PC1 2 cells. J. Neurosci. 5: 2762-2770.

Whittcmore, S. R., T. Ebendal, L. Larkfors, L. Olson, A. Seiger, I. Stromberg, and H. Persson (1986) Developmental and regional expression of $\beta$ nerve growth factor messenger RNA and protein in the rat central nervous system. Proc. Natl. Acad. Sci. USA 83: 817821.

Yip, H. K., and E. M. Johnson, Jr. (1984) Developing dorsal root ganglion neurons require trophic support from their central processes: Evidence for a role of retrogradely transported nerve growth factor from the central nervous system to the periphery. Proc. Natl. Acad. Sci. USA 81: 6245-6249.

Young, J. Z., and B. B. Medawar (1940) Fibrin suture of peripheral nerves. Measurement of the rate of regeneration. Lancet ii: 126-128.

Zimmermann, A., and A. Sutter (1983) $\beta$-Nerve growth factor ( $\beta N G F)$ receptors on glial cells. Cell-cell interaction between neurones and Schwann cells in cultures of chick sensory ganglia. EMBO J. 2: 879885 . 